\title{
Anilino-dialkoxyquinazolines: Screening Epidermal Growth Factor Receptor Tyrosine Kinase Inhibitors for Potential Tumor Imaging Probes
}

\author{
Henry F. VanBrocklinn ${ }^{1}$ *, John K. Lim ${ }^{1,2}$, Stephanie L. Coffing ${ }^{3,5}$, Darren L. Hom ${ }^{1}$, Kitaw Negash ${ }^{1,4}$, \\ Michele Y. Ono ${ }^{1}$, Jennifer L. Gilmore ${ }^{3}$, Ianthe Bryant ${ }^{3}$, and David J. Riese II ${ }^{3}$ \\ ${ }^{1}$ Department of Functional Imaging, Lawrence Berkeley National Laboratory, Berkeley, CA \\ 94720-8119 \\ 2 Department of Radiology, University of California, San Francisco, CA 94143 \\ 3 Department of Medicinal Chemistry and Molecular Pharmacology, Purdue University, 1333 \\ Heine Pharmacy Building, West Lafayette, IN 47907 \\ ${ }^{2}$ Current Address: Hitachi High Technologies America, Inc., San Jose, CA 95134 \\ 4 Current Address: American Cyanamide Co., Agricultural Research Division, Princeton, NJ \\ 08543 \\ ${ }^{5}$ Current Address: Pfizer Central Research, Groton, CT 06349
}

*Corresponding Author:

Henry F. VanBrocklin, Ph.D.

Lawrence Berkeley National Laboratory

1 Cyclotron Rd. MS55R0121

Berkeley, CA 94720-8119

Phone: 510.486.4083

Fax: 510.486.4768

E-mail: hfvanbrocklin@lbl.gov

Working Title: EGFR Inhibitors as Imaging Probes 


\begin{abstract}
The epidermal growth factor receptor (EGFR), a long-standing drug development target, is also a desirable target for imaging. Sixteen dialkoxyquinazoline analogs, suitable for labeling with positronemitting isotopes, have been synthesized and evaluated in a battery of in vitro assays to ascertain their chemical and biological properties. These characteristics provided the basis for the adoption of a selection schema to identify lead molecules for labeling and in vivo evaluation. A new EGFR tyrosine kinase radiometric binding assay revealed that all of the compounds possessed suitable affinity $\left(\mathrm{IC}_{50}=\right.$ $0.4-51 \mathrm{nM}$ ) for the EGFR tyrosine kinase. All of the analogs inhibited ligand-induced EGFR tyrosine phosphorylation $\left(\mathrm{IC}_{50}=0.8-20 \mathrm{nM}\right)$. The HPLC-estimated octanol/ water partition coefficients ranged from 2.0-5.5. Four compounds, 4-(2'-fluoroanilino)- and 4-(3'-fluoroanilino)-6,7-diethoxyquinazoline as well as 4-(3'-chloroanilino)- and 4-(3'-bromoanilino)-6,7-dimethoxyquinazoline, possess the best combination of characteristics that warrant radioisotope labeling and further evaluation in tumor-bearing mice.
\end{abstract}




\section{Introduction}

Protein tyrosine kinases (PTKs), enzymes that phosphorylate tyrosine residues on functional proteins, are common mediators of signals that regulate many cellular processes. PTKs can be divided into two subgroups based on their structural characteristics, nonreceptor cytoplasmic PTKs and receptor tyrosine kinases (RTKs). ${ }^{1}$ To date at least 20 families of receptor tyrosine kinases that share structural, most notably an intrinsic tyrosine kinase domain, and functional similarities have been classified. ${ }^{2,3}$ The epidermal growth factor receptor (EGFR) was one of the first oncogenes and receptor tyrosine kinases to be discovered. ${ }^{4,5}$ EGFR belongs to the ErbB family of receptors, which also includes ErbB2 (HER2/Neu), ErbB3 and ErbB4. These receptors are overexpressed in a variety of tumors.

EGFR tyrosine kinase phosphorylation is stimulated by epidermal growth factor (EGF) or transforming growth factor $\alpha(\mathrm{TGF} \alpha)$ binding to the extracellular ligand binding domain of the EGFR and subsequent receptor dimerization. Signal transduction initiated by these events regulates cellular proliferation, differentiation, motility, adhesion and apoptosis. These signaling processes play an important role in normal epithelial and stromal cell morphology; moreover, overexpression or aberrant signaling from EGFR and the other ErbB receptor family members has been shown to be a key determinant in tumor growth and proliferation. ${ }^{6,7}$

Overexpression of EGFR has been found in head and neck tumors, gliomas, non-small cell lung carcinoma and tumors of the breast, ovaries, cervix, esophagus, bladder, prostate, and kidney. ${ }^{7}$ There is extensive literature on the clinical significance of increased EGFR expression and signaling in tumors and the relationship to other prognostic factors. ${ }^{8,9}$ In a majority of tumors poor survival rates correlate with EGFR overexpression. For example, EGFR overexpression has been detected in nearly 45 percent of the breast tumors studied ${ }^{10}$ and receptor overexpression is inversely correlated with patient survival. ${ }^{9}$ EGFR overexpression is also inversely correlated with estrogen receptor status, consistent with the failure of EGFR positive patients to respond to hormonal therapies. ${ }^{11,12}$ The relevance of EGFR expression in tumors to prognostic outcome supports the years of investment towards finding an EGFRtargeted therapeutic ${ }^{13-18}$ and the need for a diagnostic imaging agent. Development of an imaging agent might also be a valuable tool in the search for and the characterization of EGFR-targeted therapeutics. 
Two potential targets for EGFR-based probes are the extracellular domain or the intracellular tyrosine kinase domain. Radioactive probes that bind to the extracellular domain of EGFR have been generated. EGF, the 53 amino acid, $6 \mathrm{kDa}$, natural ligand, binds to the EGFR with a $\mathrm{K}_{\mathrm{d}}$ of $0.1-1.0 \mathrm{nM}^{19}$ and has been labeled directly with iodine-123, iodine-125 and iodine-131. In vitro studies using $\left[{ }^{131}\right.$ I]EGF demonstrated its cytotoxic potential. ${ }^{20} 123$ I-EGF has been used to image cervical cancer in humans. ${ }^{21}$ In spite of its ability to localize in EGFR rich tissue, radioiodinated EGF rapidly degrades in vivo releasing radioiodine thereby reducing the lifetime of the label in the tumor. ${ }^{22}$ Iodinated dextranEGF conjugates increase retention of the iodine by tumor cells but at the cost of higher molecular weight that affects tracer distribution. ${ }^{20}$ EGF has been labeled with technetium-99m using a MAG3 or 2iminothiolane chelate and was found to accumulate in tumor xenografts with more rapid clearance than labeled monoclonal antibodies (Mabs). ${ }^{23-25}$ Bifunctional chelation of indium-111 to EGF using diethylenetriaminepentaacetic acid (DTPA) has been shown to have cytotoxic effects in vitro and is being investigated as a potential radiotherapeutic agent. ${ }^{26,27}$ The imaging potential of ${ }^{111} \mathrm{In}$-EGF was found to be inferior to a labeled anti-EGFR antibody, ${ }^{111}$ In-DTPA-MAb 528 in tumor bearing rats. ${ }^{28}$

Several MAbs against EGFR have been developed as anti-tumor agents. The radioiodinated Mab, EGFR1, with high affinity for the EGFR has demonstrated good uptake in MCF-7 tumors grown in nude athymic mice ${ }^{29}$ and good localization in human brain gliomas. ${ }^{30}$ Likewise, the indium-111 labeled C225 Mab has been tested in patients with squamous cell lung carcinoma. ${ }^{31}$ A direct-labeled technetium-99m anti-EGFR antibody, ior egfr/r3, has demonstrated imaging sensitivity (84\%), specificity $(100 \%)$ and accuracy $(86.5 \%)$ in human epithelial tumors. ${ }^{32}$ However, MAbs labeled with short-lived PET isotopes, in general, have demonstrated limited targeting success in large part due to pharmacokinetic constraints related mostly to their size.

To date no small organic molecules with affinity for the extracellular domain of the EGFR have been identified; however, a number of small molecules have been shown to be potent (nM to pM) inhibitors of the intracellular EGFR tyrosine kinase at the ATP binding site. A sampling of the different compound classes that inhibit EGFR phosphorylation is shown in Figure 1. The dialkoxy- 
anilinoquinazolines (Figure 1) were chosen as the lead compounds in the present study based on the strong structure-activity data. ${ }^{33-35}$

The development of imaging agents based on the small molecule EGFR inhibitors has been a recent area of active research. A number of radiolabeled anilinoquinazoline analogs have been reported. The compounds incorporate labeled substituents on the A or C rings (see Figure 1) of the anilino- or benzylamino- quinazoline. The $\mathrm{C}$ ring substituted analogs include 4-(3'-[ $\left.{ }^{125} \mathrm{I}\right]$ iodoanilino ${ }^{36,37}$, 4- $\left(3^{\prime}-\right.$ $\left[{ }^{18} \mathrm{~F}\right]$ fluoro-5'-trifluoromethylanilino)- ${ }^{38}, 4-\left(3^{\prime}, 4^{\prime}-\right.$ dichloro- 6 '- $\left[{ }^{18} \mathrm{~F}\right]$ fluoroanilino $)-{ }^{38}$, and $4-\left(3^{\prime}-\mathrm{chloro}-4\right.$ '$\left[{ }^{18} \mathrm{~F}\right]$ fluoroanilino $)-{ }^{39}$. The $7-\left[{ }^{18} \mathrm{~F}\right]$ fluoroethoxy- ${ }^{40}$ and the 6- or $7-\left[{ }^{11} \mathrm{C}\right]$ methoxy- ${ }^{40,41}$ constitute the A ring labeled analogs. Preliminary in vitro studies with the $3^{\prime}-\left[{ }^{125} \mathrm{I}\right]$ iodo analog demonstrated receptor mediated uptake in cells containing high EGFR titer. ${ }^{37}$ A study of the carbon-11 methoxy derivative demonstrated some uptake in human neuroblastoma xenografts in mice ${ }^{42,43}$; however, the 20 min halflife of the carbon-11 may not allow adequate time for the development of good signal relative to background. Bonasera and colleagues evaluated five fluorine-18 labeled compounds. ${ }^{38}$ They studied the 4-(4'-[ $\left.{ }^{18} \mathrm{~F}\right]$ fluoroanilino)-dimethoxyquinazoline and the 4-(3',4'-dichloro-6'-[ $\left[{ }^{18} \mathrm{~F}\right]$ fluoroanilino)dimethoxyquinazoline in tumor-bearing mice. These tracers did not accumulate in the tumors nor was receptor-mediated uptake, based on blocking studies, observed for the latter probe. Low receptor affinity, high non-specific binding and probe metabolism may have contributed to the inability of these compounds to accumulate in tumor cells that overexpress EGFR.

Successful development of an imaging probe targeting a new biomarker, in this case EGFR, requires an adequate screening strategy for the selection of ligands to be carried forward for labeling and, ultimately, in vivo studies. It is neither economically nor logistically feasible to label and evaluate every compound in animal models. Likewise, navigating the structure activity relationships in the medicinal chemistry literature can be challenging with respect to choosing an appropriate imaging lead compound. For example, the fact that a small molecule is a potent EGFR inhibitor does not necessarily guarantee that it will possess desirable EGFR imaging characteristics such as high receptor affinity, high receptor selectivity, low non-specific binding, rapid clearance and suitable metabolism. 
In the current study, a small series of dialkoxyquinazoline EGFR inhibitors suitable for labeling with fluorine-18 (110 min half-life positron-emitter) or carbon-11 (20 min half-life positron-emitter) has been synthesized. Appropriate assays have been developed to determine both functional and imaging characteristics, including a new radiometric binding assay to measure the affinity of the inhibitors for the enzyme. These studies provide the basis needed for the selection of ligands to be labeled and further evaluated as potential imaging agents for the non-invasive determination of EGF receptor density.

\section{Results}

\section{Chemistry.}

A small library of anilino- and benzyl-dialkoxyquinazoline compounds 10-17 were prepared by coupling 4-chloro-dialkoxyquinazoline $\mathbf{8}$ or $\mathbf{9}$ with the appropriate substituted aniline or benzylamine (Scheme 3). The 4-chloro-6,7-dimethoxyquinazoline was synthesized as previously reported from the 4,5-dimethoxyanthranilic acid 5. ${ }^{33}$ As the 4-(3'-bromoanilino)-6,7-diethoxyquinazoline was reported ${ }^{33}$ to possess more potent biological activity than the corresponding 6,7-dimethoxy analog, we were interested in finding a convergent synthetic route suitable for the preparation of several diethoxy analogs. The previously reported two step conversion of the dimethoxy-bromoanilinoquinazoline 11c to the diethoxy analog 10c (Scheme 3), using a pyridinium hydrochloride melt to give the bishydroxy intermediate followed by O-alkylation with iodoethane, proceeded in a low $5.5 \%$ yield. ${ }^{33}$ This was inadequate for the preparation of a series of the diethoxy analogs. Thus, we produced the 4,5diethoxyanthranilic acid 4 by two methods (Scheme 1). Initially, a small amount of methyl 2-amino-4,5diethoxybenzoate $\mathbf{3}$ was commercially available from Aldrich Specialty Chemical. The benzoate $\mathbf{3}$ was directly converted to $\mathbf{4}$ by saponification of the methyl ester. Alternatively, when the commercial supply was depleted, 4,5-diethoxybenzoic acid $\mathbf{1}$ was nitrated to give $\mathbf{2}$ followed by reduction of the nitro group to form the desired amino-benzoic acid $\mathbf{4}$ in moderate overall yield.

Preparation of the 4-chloroquinazolines followed a previously described procedure (Scheme 2). ${ }^{33}$ Cyclization of the dialkoxyanthranilic acids, 4 or 5, with formamidine hydrochloride at $210^{\circ} \mathrm{C}$ gave the corresponding dialkoxyquinazolinones, 6 or 7, in 55-65\% yield. The quinazolinones were subsequently 
refluxed with oxalyl chloride in DMF and 1,2-dichloroethane to form the 4-chloro-dialkoxyquinazolines 8 and 9 in good yield.

A modified coupling procedure was employed for the production of the anilino- and benzylaminoquinazolines (Scheme 3). Anhydrous DMF was used as the reaction solvent instead of the previously reported isopropanol. The reaction was carried out at $80^{\circ} \mathrm{C}$ with nearly quantitative conversion to the substituted aminoquinazoline hydrochloride $(\mathrm{HCl})$ salt within $30 \mathrm{~min}$ to $1 \mathrm{~h}$ depending on the aniline substituents. The precipitated $\mathrm{HCl}$ salt was filtered from the DMF solution and was converted to the free base for semi-preparative normal phase HPLC purification. The pure quinazolines were reconverted to the more stable $\mathrm{HCl}$ salt for the biological assays.

Chemical and physical data for all of the compounds is presented in Table 1. All of the anilino- and benzyl- quinazoline analogs were analyzed by analytical reversed-phase HPLC and found to be greater than $99 \%$ pure. Elemental analysis of all of the dialkoxyquinazoline analogs in Table 1 agree with the calculated values to within $\pm 0.4 \%$

\section{Lipophilicity measurement.}

The lipophilicity of compounds can affect their tissue permeability properties that can impact their localization in target tissues. Lipophilicity may also affect binding to low affinity nonspecific sites that can compromise target tissue to background tissue ratios. The octanol/water partition coefficients of the quinazoline compounds were estimated by a reversed-phase HPLC method. ${ }^{44}$ This method has been previously used by us to determine lipophilicities of steroid ligands. ${ }^{45}$ The estimated Log $\mathrm{P}_{\mathrm{o} / \mathrm{w}}$ values are reported in Table 1. The lipophilicities generally exhibited the expected trends with a couple of noted exceptions. The lipophilicity was greater for the diethoxy series relative to the corresponding dimethoxy analogs. Within the series 10a-d and 11a-d the lipophilicity increased with increasing size of the halogen from fluorine to iodine. Adding the trifluoromethyl moiety to 10a and 11a increased the lipophilicity by 1.7-1.8 log units. Interestingly, adding an extra methylene to produce the benzylamine did not significantly increase the compound lipophilicity (compare 14 and $\mathbf{1 6 b}, 15$ and $\mathbf{1 7 b}$ ). In contrast, the position of the fluorine on the aniline (C ring, Figure 1) ring did have a significant effect on the lipophilicity. The meta- and para- fluoroanilino analogs, 10a and 16b, had similar lipophilicities while 
the ortho- substituted analog, 16a, showed a $0.7 \log$ unit decrease. This trend was similar for the dimethoxy analogs.

\section{Biological Activity.}

The sixteen quinazoline compounds were studied in a battery of in vitro assays to assess their biological properties and to develop a basis for screening these and future compounds for potential imaging agents. A radiometric binding assay was developed to determine the relative binding affinities of these compounds for the ATP binding site in the tyrosine kinase domain of the receptor. The ability of these molecules to inhibit EGFR tyrosine phosphorylation was probed. The specificity of a small subset of compounds was determined by assessing inhibition of ErbB2 and ErbB4 receptor phosphorylation. Finally, the ability of the ligand to inhibit cellular DNA synthesis, in cells dependent and not dependent on EGF for cell proliferation, was evaluated. This assay was performed in an effort to find a test that would be amenable to high throughput screening and whose results would potentially correlate with receptor binding and ultimately with the pharmacokinetic distribution of the tracer in vivo.

Receptor binding is a key characteristic that these molecules must possess to be suitable imaging agents. A receptor binding assay using EGF receptors extracted from the A431 human carcinoma cell membranes was developed and used to study the relative binding affinity of these compounds to the tyrosine kinase domain. Iodine-125 labeled 11d (specific activity 583-596 Ci/mmol) was employed as the radioligand ${ }^{36}$ and non-specific binding was determined by adding 11c, the bromo- analog, to the assay. EGFR binding values, expressed as an $\mathrm{IC}_{50}$, are shown in Table 2. All of the compounds demonstrated high affinity for the receptor with $\mathrm{IC}_{50} \mathrm{~S}$ ranging from $0.4-51 \mathrm{nM}$. In all cases the diethoxy analogs had relatively higher affinity for the receptor than the corresponding dimethoxy derivatives. Analogs 10b-10d and 11b-11d, the meta- chloro-, bromo- and iodo-anilino analogs, exhibited the highest relative affinities (nanomolar to subnanomolar) for the tyrosine kinase domain. Three fluoroanilino analogs, 10a, 12, and 16a displayed relative affinities slightly less than $10 \mathrm{nM}$,

generally considered the upper limit for imaging agents ${ }^{46,47}$, while the remaining analogs had relative affinities greater than $16 \mathrm{nM}$. 
While receptor binding is absolutely necessary for localization of a potential imaging agent, the ability to inhibit receptor function, in this case ligand-induced receptor tyrosine autophosphorylation, may be uncoupled from ligand binding. A series of assays were designed to examine the correlation between receptor binding and inhibition of receptor phosphorylation or inhibition of EGF-dependent DNA synthesis. The inhibition of ligand-induced EGFR tyrosine autophosphorylation is reported in Table 2. All of the compounds were potent inhibitors of EGFR tyrosine phosphorylation (kinase activity) with the exception of the 4-(3'-fluoro-5'-trifluoromethylanilino)-6,7-diethoxyquinazoline analog 12. There was no correlation $\left(r^{2}=0.02\right)$ between binding affinity and inhibition of ligandinduced EGFR tyrosine phosphorylation. Indeed, in contrast to the results of the receptor binding assay, in the EGFR tyrosine phosphorylation assays the diethoxy analogs were not consistently better inhibitors than the corresponding dimethoxy analogs.

Specificity for the EGF receptor versus other receptor tyrosine kinases, especially ErbB2 and ErbB4, is another desirable imaging characteristic. Thus, a small set of compounds was evaluated for inhibition of ligand-induced ErbB2 and ErbB4 tyrosine phosphorylation (kinase activity). The specificity of the compounds tested for EGFR appears to be high (Table 2). For the four compounds tested (10c, 10d, 11c, and 14), the ErbB2 and ErbB4 tyrosine phosphorylation (kinase) $\mathrm{IC}_{50}$ values were at least one order of magnitude greater than the EGFR tyrosine phosphorylation (kinase) $\mathrm{IC}_{50}$ values. We do recognize that this is a comparison of phosphorylation inhibition rather than binding.

The specificity of the molecules for EGFR was also determined by examining their effect on DNA synthesis by the EGF-dependent MCF-10A human mammary epithelial cell line and the EGFindependent MCF-7 human mammary tumor cell line. These cell lines were treated with various concentrations of several of the compounds and DNA synthesis was measured by assaying ${ }^{3} \mathrm{H}$-thymidine incorporation. These data were used to calculate the DNA synthesis $\mathrm{IC}_{50}$ values for each compound in the two cell lines, shown in Table 3. The MCF7 DNA synthesis $\mathrm{IC}_{50}$ values for the compounds were at least one order of magnitude higher than the corresponding MCF10A DNA synthesis $\mathrm{IC}_{50}$ values. Because the DNA synthesis of MCF10A cells is EGF-dependent, these data suggest that the compounds inhibit MCF10A DNA synthesis by inhibiting the EGFR rather than some other target. 


\section{Discussion}

There are four well-established criteria for the development of disease-specific radioprobes that would be sensitive to changes in binding site concentration. ${ }^{46,47}$ They are: i) identify a binding site whose concentration changes as a function of a specific disease; ii) design and produce a radioprobe that selectively targets the binding site; iii) evaluate sensitivity as a function of altered binding site concentration; and iv) evaluate sensitivity relative to the selected disease. The EGF receptor overexpression in various tumors satisfies the first criterion. Identifying lead molecules to test as imaging probes and developing an underlying selection process to identify future candidate molecules, the subject of the present effort, begins to address the second criterion.

Designing and producing an enzyme- or receptor-binding radioprobe involves several steps, often an iterative process, intended to obtain a thorough understanding of the biochemical and

physiological behavior of the probe to match against a set of desirable imaging characteristics. ${ }^{46,47} \mathrm{~A}$ receptor-binding radiotracer should meet the following criteria: i) high affinity for the desired enzyme or receptor, typically $<10 \mathrm{nM}$; ii) appropriate lipophilicity (coupled to cell membrane or blood-brain barrier penetration, typically $1.5-3.0$ ); iii) high selectivity for the enzyme or receptor (e.g. low affinity for receptors within the same family or similar proteins, typically $>10: 1$ ); iv) suitable metabolic properties (labeled metabolites can alter the distribution profile of the probe); and v) rapid clearance from non-target tissues and the body (necessary for good target-to-background ratio, typically $>3: 1$ and lower radiation dose to the subject). In vitro data for a series of dialkoxyquinazoline EGFR-targeted compounds have been gathered and used to select probes for labeling and in vivo evaluation. These data were used to establish a ligand selection process. The process is detailed in the context of the following discussion.

The dialkoxyquinazolines (Figure 1) were chosen as the lead compounds in the present study based on the reported structure inhibition relationships. ${ }^{33-35}$ Fry and colleagues demonstrated that the quinazoline backbone and the 6,7-dimethoxy moieties were necessary for enhanced EGFR tyrosine kinase inhibition. The 6,7-diethoxy analog 10c exhibited a four-fold lower inhibition $\mathrm{IC}_{50}$ value $(6 \mathrm{pM}$ 
vs $25 \mathrm{pM}$ ) and halogen substitution at the $2^{\prime}, 3^{\prime}, 4^{\prime}$ and $5^{\prime}$ positions, even $3^{\prime}, 4^{\prime}$ dibromination, of the anilino ring ("C" ring Figure 1) was well tolerated. The fluorobenzylamino analog was not previously studied but based on the radiochemical availability of this analog it was included here. ${ }^{48}$ The unsubstituted benzyl compound was evaluated as an inhibitor and found to have a 3 fold lower inhibition $\mathrm{IC}_{50}$ value $(10 \mathrm{nM})$ compared to the corresponding unsubstituted anilino compound (29 $\mathrm{nM}){ }^{33,35}$ The 3-fluoro-5-trifluoromethylaniline as well as 2-, 3- and 4- fluoroaniline can be synthesized with fluorine-18 so the corresponding non-radioactive analogs were added to the study. ${ }^{49}$ Inhibition data from the 4-(3'-trifluoromethylanilino)-6,7-dimethoxyquinazoline (inhibition $\mathrm{IC}_{50}=0.24 \mathrm{nM}$ ) and the 3'fluoroanilino analog (inhibition $\mathrm{IC}_{50}=3.8 \mathrm{nM}$ ) supported their inclusion.

The preparation of the analogs for this study was straightforward. The 4-chloro- dimethoxy- or diethoxy-quinazoline intermediates were synthesized and coupled with the appropriate aniline or benzylamine to yield the desired anilino- or benzylamino-quinazolines in good yield. The approach outlined herein improved upon the chemistry previously described by Bridges et al..$^{33}$ and provides a suitable starting point to generate libraries of anilino- or benzylamino- quinazolines with any dialkoxy or mixed alkoxy substituents in the 6 and 7 positions.

A receptor binding assay was developed to study the affinity of the compounds for the tyrosine kinase binding site and determine the correlation, if any, between binding and inhibition values. In vitro equilibrium binding assays provide a good means of segregating potential receptor-based imaging agents from those whose unfavorable kinetics (high binding potential, $\mathrm{B}_{\max } / \mathrm{K}_{\mathrm{d}}$ ) might lead to flow mediated distribution. ${ }^{47}$ As all of the literature for the quinazolines and other classes of compounds targeting the EGFR tk reported inhibition constants, the following question was posed: Could these values be used as a primary determinant for potential imaging probes? All of the compounds possessed suitable affinity for the EGFR tk $\left(\mathrm{IC}_{50}\right.$ range $\left.=0.4-51 \mathrm{nM}\right)$. Likewise, all of the compounds were $\mathrm{nM}$ inhibitors of ligand-induced EGFR tyrosine phosphorylation $\left(\mathrm{IC}_{50}\right.$ range $\left.=0.8-23.1 \mathrm{nM}\right)$ in whole cells. Yet, there was a complete lack of correlation between the matched set of binding and phosphorylation data. Based on this small set of compounds the phosphorylation data may not be used to predict receptor affinity. This is likely due to the fact that inhibition of ligand-induced receptor phosphorylation is not 
only a function of receptor binding affinity, but is also a function of the ability to penetrate a cell and gain access to the receptor. Thus, the receptor binding assay along with a measure of cell penetration (inhibition of EGFR dependent DNA synthesis, see below) will be integral as an initial screen for tracers. Compounds 10a-d, 11b-d, 12 and 16a meet the generally accepted minimum affinity for receptor-based imaging agents, $10 \mathrm{nM}$.

A subsequent screen of selected lead compounds for the inhibition of ligand-induced tyrosine phosphorylation will identify those molecules that readily access the receptor. For example, compound 12 has a suitable affinity for EGFR in vitro but displays minimal inhibition of ligand-induced receptor tyrosine phosphorylation. Thus, compound $\mathbf{1 2}$ probably possesses limited penetration of cells and/or limited EGFR access. Therefore, compound $\mathbf{1 2}$ is likely to be of limited value as a potential EGFRspecific tumor imaging agent. Compounds 10a-d, 11b-d, and 16a are potent inhibitors of EGFR phosphorylation.

In cases where facilitated transport is nonexistent cell membrane permeability is a direct function of the diffusion coefficient and compound lipophilicity. If the partition coefficient value is too low, the compound will not cross a cell membrane; if the value is too high, hydrophobic interactions with lipids and proteins will dominate, leading to high non-specific binding, compromising image contrast. It has been demonstrated for radiotracers crossing the blood-brain barrier that a $\log \mathrm{P}_{\mathrm{o} / \mathrm{w}}$ range of $1.5-3$ is optimal. ${ }^{56}$ While this range works equally well for non-brain receptor-targeted tracers, estrogen radioprobes with higher lipophilicity (up to $\log \mathrm{P}=4.5$ ) have been successful tumor imaging agents. ${ }^{57}$ Therefore, the $\log \mathrm{P}_{\mathrm{o} / \mathrm{w}}$ range for the selection of the EGFR probes in the current study has been set from 1.5 to 4 . The HPLC derived lipophilicities $\left(\log \mathrm{P}_{\mathrm{o} / \mathrm{w}}\right.$ ) ranged from 2.2 to 5.5. Of those compounds previously chosen, 10a and $\mathbf{1 1 b}-\mathbf{d}$ and $\mathbf{1 6 a}$ fall within this desired range.

Selectivity for the chosen receptor is the final in vitro test. One preliminary measure of receptor selectivity that was employed in this study was to evaluate ErbB2 and ErbB4 inhibition. All of the compounds were much less potent inhibitors of ligand-induced ErbB2 and ErbB4 phosphorylation than of ligand-induced EGFR phosphorylation. Indeed the compounds tested here exhibit between one and two orders of magnitude of selectivity for the EGFR over ErbB2 or ErbB4. All of the compounds tested 
may be reasonable EGFR-selective tumor imaging agents. The optimal agent would exhibit the least amount of avidity for other RTKs. In many types of tumor cells ErbB2 is frequently overexpressed at levels comparable to the levels of EGFR overexpression. ${ }^{7}$ Similarly, ErbB4 is expressed in the normal mammary epithelium ${ }^{59}$ and infrequently overexpressed in tumor tissue. ${ }^{58,59}$ These observations highlight the need for EGFR-selective imaging agents that exhibit minimal binding to ErbB2 and ErbB4, among other RTKs, in order to determine and understand EGFR expression using molecular imaging techniques.

The quinazoline compounds were also assayed for inhibition of cellular DNA synthesis in EGFdependent (MCF10A) and EGF-independent (MCF7) cell lines. This assay, like the inhibition of ligand-induced receptor tyrosine phosphorylation assays, not only assesses the specificity of a compound for EGFR, but also provides a measure of a compounds ability to penetrate cells and specifically target the EGFR. Thus, it is not surprising that compound 12, which we hypothesized failed to inhibit ligand-induced EGFR tyrosine phosphorylation because it exhibits limited cell penetration, also failed to inhibit EGF-dependent and -independent DNA synthesis.

In general, the MCF10A DNA synthesis $\mathrm{IC}_{50}$ values are much lower than the MCF7 DNA synthesis $\mathrm{IC}_{50}$ values. This suggests that the compounds inhibit DNA synthesis in the MCF10A cells by primarily targeting EGFR. Indeed, this assay has been used to connote that Lavendustin A analogs, which inhibit EGFR kinase activity, inhibit cell proliferation by inhibiting tubulin polymerization. ${ }^{50}$ This indicates that at least some of the compounds inhibit DNA synthesis in the MCF7 cells by targeting a protein other than the EGFR. Compounds that may target ATPases other than the EGFR would be expected to exhibit reduced MCF7/MCF10A DNA synthesis IC $_{50}$ ratios. Compounds with reduced ratios include 11d, 13, and 17b. Such molecules may not be specific for the EGFR and may not be appropriate for further investigation as potential EGFR-specific tumor imaging agents. Compounds 10ad, 11b,c, 14, 16a,b and 17a exhibit elevated MCF7/MCF10A DNA synthesis $\mathrm{IC}_{50}$ ratios and by this criterion may be suitable for further investigation as a potential EGFR-specific tumor imaging agents.

These criteria taken together support the further investigation of compounds 10a, 11b, 11c and 16a. Compounds 10a, 4-(3'-fluoroanilino)- and 16a, 4-(2'-fluoroanilino)-6,7-diethoxyquinazoline, may 
both be labeled with the $110 \mathrm{~min}$ half-life fluorine-18. Compound 11b, 4-(3'-chloroanilino)-6,7dimethoxyquinazoline may be labeled with the 20 min half-life carbon-11; however, as pointed out earlier, the short half-life may not afford the time necessary to achieve the desired imaging pharmacokinetics. Compound 11c 4-(3'-bromoaniline)-6,7-dimethoxyquinaxoline may be a candidate for bromine-76 (16.2h positron emitter) labeling.

Interestingly, Bonasera et al. ${ }^{38}$, have recently labeled three of the analogs studied in this paper, 11a, 13 and 17b, and injected one of them, 17b, into A431 tumor-bearing mice. Compound 13 was not studied in vivo due to low measured EGFR inhibition values and compound 11a was not readily labeled with fluorine-18. Tumor uptake of $\left[{ }^{18} \mathrm{~F}\right] \mathbf{1 7 b}$ at 30 minutes was greater than $1 \%$ of the injected dose per gram $(\% \mathrm{ID} / \mathrm{g})$ of tissue but the tumor to blood ratio was only 0.6 . At 60 minutes the tumor uptake rose slightly to $1.34 \% \mathrm{ID} / \mathrm{g}$ with a tumor to blood ratio of 1.62 . This uptake may be associated with EGFR targeting but receptor blocking studies were not performed to demonstrate receptor mediated uptake. Bone uptake, an indicator of metabolic defluorination, was also not assessed. A second fluorine-labeled analog, 4-(3', 4'- dichloro-6'-fluoroanilino)-6,7-dimethoxyquinazoline, was tested in tumor-bearing mice. Tumor accumulation of the probe never exceeded blood levels and the uptake was not receptormediated. Several factors may have contributed to the limited tumor accumulation in vivo including high non-specific binding or diminished availability due to untoward metabolism.

It is clear from the preliminary studies that development of an effective EGFR imaging probe may present some challenges. Thus, effective screening of candidate probes and establishment of baseline data is essential for a radiopharmaceutical development program targeting EGFR.

\section{Conclusion}

Anilino-dialkoxyquinazolines suitable for labeling with radioisotopes were readily prepared using an approach amenable to a synthetic library of amino-quinazoline analogs. All of the dialkoxy analogs possessed suitable affinity for the EGF receptor and all analogs were potent inhibitors of ligandinduced EGFR phosphorylation. They exhibited a range of lipophilicities based on the A ring and $\mathrm{C}$ ring substituents. Selectivity, as determined by comparison of ErbB2 and ErbB4 receptor inhibition to EGFR inhibition, favored the EGFR by 1-2 orders of magnitude. Based on measures of affinity, lipophilicity 
and selectivity, analogs 10a, 11b, 11c and 16a, were selected for further evaluation as tumor imaging probes. 


\section{Experimental Section}

Chemistry. Unless otherwise noted, all solvents and reagents were obtained from commercial suppliers (Aldrich Chemical, Co., Lancaster Synthesis, Inc., VWR, etc.) and were used without further purification. Melting points were determined using a Mel-Temp melting point apparatus and are reported uncorrected. NMR spectra were recorded on either a Bruker VBAMX $300300 \mathrm{MHz}$ or AMX $400400 \mathrm{MHz}$. Chemical shifts are reported in ppm $(\delta)$ relative to an internal standard. Elemental analyses were performed by the Microanalytical Laboratory in the College of Chemistry, University of California, Berkeley. Mass spectral data was obtained on a Perkin Elmer SCIEX mass spectrometer at the SynPep Corporation facility (Dublin, CA) or on a VG ProSpec mass spectrometer at the Mass Spectrometry Facility in the College of Chemistry, University of California, Berkeley.

2-nitro-4,5-diethoxybenzoic acid (2). A flask immersed in a room-temperature water bath was charged with 3,4-diethoxybenzoic acid 1 (12.9 g, $61.4 \mathrm{mmol})$ and acetic acid (glacial, $52 \mathrm{~mL})$. Over a 15 min. period $\mathrm{HNO}_{3}(70 \%, 54 \mathrm{~mL})$ was added dropwise with stirring. The deep orange solution was stirred for an additional $125 \mathrm{~min}$. at room temperature. The reaction was quenched upon addition of 110 $\mathrm{g}$ of ice. A yellow precipitate formed, which was filtered and washed with $\mathrm{H}_{2} \mathrm{O}(3 \times 50 \mathrm{~mL})$. The resulting yellow-white solid was dissolved in ether $(150 \mathrm{~mL})$. The ether was washed with $1 \mathrm{~N} \mathrm{NaOH}(3$ x $60 \mathrm{~mL}$ ). The aqueous washings were combined, and acidified with concentrated $\mathrm{HCl}$ resulting in the production of a pale yellow precipitate. The precipitate was filtered, washed with $\mathrm{H}_{2} \mathrm{O}(3 \times 100 \mathrm{~mL})$ and dissolved in ether. The ether was dried over $\mathrm{MgSO}_{4}$, and concentrated in vacuo to yield $10.55 \mathrm{~g}$ $(67 \%)$ of $2 . \mathrm{mp} 142-145{ }^{\circ} \mathrm{C} ;{ }^{1} \mathrm{H}-\mathrm{NMR}\left(\mathrm{CDCl}_{3}\right): \delta 7.36(\mathrm{~s}, 1 \mathrm{H}, H-6), 7.21(\mathrm{~s}, 1 \mathrm{H}, H-3), 4.20(\mathrm{q}, 2 \mathrm{H}$, $\left.\mathrm{CH}_{2} \mathrm{CH}_{3}, \mathrm{~J}=6.9 \mathrm{~Hz}\right), 4.17\left(\mathrm{q}, 2 \mathrm{H}, \mathrm{CH}_{2} \mathrm{CH}_{3}, \mathrm{~J}=6.9 \mathrm{~Hz}\right), 1.50\left(\mathrm{t}, 6 \mathrm{H}, \mathrm{CH}_{2} \mathrm{CH}_{3}, \mathrm{~J}=7.1 \mathrm{~Hz}\right)$. EI MS [M+] 255 (100).

2-amino-4,5-diethoxybenzoic acid (4). a) A round-bottom flask containing 2-amino-4,5-diethoxymethyl benzoate 3 (1.00 g, 4.19 mmol, Sigma-Aldrich Rare Chemicals) was mixed with 6.25N NaOH $(2.67 \mathrm{~mL}, 16.7 \mathrm{mmol})$ and water $(5.0 \mathrm{~mL})$. The solution was refluxed for one hour to give a clear brown 
solution. After cooling at ambient temperature for 10 minutes, water $(15 \mathrm{~mL})$ was added to the flask and the solution was titrated to $\mathrm{pH} 6$ with $1 \mathrm{~N} \mathrm{HCl}$. The solution was further cooled in an ice bath for 30 minutes. The precipitate was filtered, washed with water $(100 \mathrm{~mL})$ and pentanes $(50 \mathrm{~mL})$ and dried in vacuo over $\mathrm{P}_{2} \mathrm{O}_{5}$ overnight to give $0.83 \mathrm{~g}(76 \%)$ of 2-amino-4,5-diethoxybenzoic acid as a pale yellow solid.

b) An oven-dried round-bottomed flask $(250 \mathrm{~mL})$ equipped with a stirring bar was immersed in a roomtemperature water bath and charged with $\mathrm{SnCl}_{2} \cdot 2 \mathrm{H}_{2} \mathrm{O}(24.9 \mathrm{~g}, 110 \mathrm{mmol})$ and $\mathrm{HCl}$ (conc., $\left.100 \mathrm{~mL}\right)$. 2Nitro-4,5-diethoxybenzoic acid 2 (1.64 g, $6.43 \mathrm{mmol})$ was added and the mixture was stirred for 120 min. at room temperature. The mixture was diluted with $\mathrm{HCl}$ (conc., $40 \mathrm{~mL}$ ), filtered, and washed with conc. $\mathrm{HCl}$. The resulting white solid was taken up in $\mathrm{H}_{2} \mathrm{O}(500 \mathrm{~mL})$ and filtered to remove the remaining undissolved material. The $\mathrm{pH}$ of the filtrate was adjusted to 4.5 using $\mathrm{NH}_{4} \mathrm{OH}$. The deep purple solution was extracted with $\mathrm{CH}_{2} \mathrm{Cl}_{2}(3 \times 300 \mathrm{~mL})$. The organic washings were combined, dried over $\mathrm{MgSO}_{4}$, and concentrated in vacuo, to yield $0.64 \mathrm{~g} \mathrm{(44 \% )}$ of a purple-white powder.

mp 120-126 ${ }^{\circ} \mathrm{C} ;{ }^{1} \mathrm{H} \mathrm{NMR}\left(\mathrm{CDCl}_{3}\right): \delta 7.37(\mathrm{~s}, 1 \mathrm{H}, H-6), 6.11(\mathrm{~s}, 1 \mathrm{H}, H-3), 4.06\left(\mathrm{q}, 2 \mathrm{H}, \mathrm{CH}_{2} \mathrm{CH}_{3}, \mathrm{~J}=6.8\right.$ $\mathrm{Hz}), 4.01\left(\mathrm{q}, 2 \mathrm{H}, \mathrm{CH}_{2} \mathrm{CH}_{3}, \mathrm{~J}=6.8 \mathrm{~Hz}\right), 1.46\left(\mathrm{t}, 3 \mathrm{H}, \mathrm{CH}_{2} \mathrm{CH}_{3}, \mathrm{~J}=6.8 \mathrm{~Hz}\right), 1.41\left(\mathrm{t}, 3 \mathrm{H}, \mathrm{CH}_{2} \mathrm{CH}_{3}, \mathrm{~J}=6.8\right.$ Hz). EI MS [M+] 225 (100).

6,7-diethoxyquinazolin-4-one (6). A modified literature procedure ${ }^{33}$ was developed to produce 6. A $500 \mathrm{~mL}$ round bottom flask equipped with an air condenser was charged with 2-amino-4,5diethoxybenzoic acid $4(1.36 \mathrm{~g}, 6.04 \mathrm{mmol})$ and formamidine hydrochloride $(0.70 \mathrm{~g}, 8.76 \mathrm{mmol})$. The solids were thoroughly mixed then heated to $200{ }^{\circ} \mathrm{C}$ under an argon atmosphere for 15 minutes. The heating block temperature was adjusted to $80{ }^{\circ} \mathrm{C}$ and the solution cooled to $80{ }^{\circ} \mathrm{C}$ over 40 minutes. Dilute $\mathrm{NaOH}(0.33 \mathrm{~N}, 20 \mathrm{~mL})$ was added to the flask. The mixture was sonicated at room temperature for 1 hour producing in a dark gray-purple suspension. The solid was filtered, washed with water (200 
$\mathrm{mL})$, pentanes $(200 \mathrm{~mL})$, and ethyl acetate $(200 \mathrm{~mL})$ to give 6,7-diethoxy-quinazolin-4-one as an offwhite solid. Drying in vacuo overnight over $\mathrm{P}_{2} \mathrm{O}_{5}$ gave $0.80 \mathrm{~g}(57 \%)$ of 6. mp $248-251.5{ }^{\circ} \mathrm{C}$; ${ }^{1} \mathrm{H}-\mathrm{NMR}$ $\left(\mathrm{CD}_{3} \mathrm{OD}\right): \delta 7.98(\mathrm{~s}, 1 \mathrm{H}, \mathrm{ArH}), 7.55(\mathrm{~s}, 1 \mathrm{H}, \mathrm{ArH}), 7.11(\mathrm{~s}, 1 \mathrm{H}, \mathrm{ArH}), 4.20\left(\mathrm{q}, 2 \mathrm{H}, \mathrm{CH}_{2} \mathrm{CH}_{3}, \mathrm{~J}=6.8 \mathrm{~Hz}\right)$, $4.16\left(\mathrm{q}, 2 \mathrm{H}, \mathrm{CH}_{2} \mathrm{CH}_{3}, \mathrm{~J}=6.8 \mathrm{~Hz}\right), 1.48\left(\mathrm{t}, 3 \mathrm{H}, \mathrm{CH}_{2} \mathrm{CH}_{3}, \mathrm{~J}=6.8 \mathrm{~Hz}\right), 1.46\left(\mathrm{t}, 3 \mathrm{H}, \mathrm{CH}_{2} \mathrm{CH}_{3}, \mathrm{~J}=6.8 \mathrm{~Hz}\right)$. EI MS [M+] $234(100)$.

6,7-dimethoxyquinazolin-4-one (7). 2-amino-4,5-dimethoxybenzoic acid 5 (5.0 g, $25.3 \mathrm{mmol})$ was converted to 7 in $65 \%$ yield $\left(3.64 \mathrm{~g}\right.$ ) following the procedure for compound 6. $\mathrm{mp} 278-278.5{ }^{\circ} \mathrm{C}$; (lit. ${ }^{33}$ mp 295-298 $\left.{ }^{\circ} \mathrm{C}\right){ }^{1} \mathrm{H}-\mathrm{NMR}\left[\left(\mathrm{CD}_{3}\right)_{2} \mathrm{SO}\right]: \delta 12.07$ (br s, 1H, NH), $7.98(\mathrm{~s}, 1 \mathrm{H}, \mathrm{ArH}), 7.43(\mathrm{~s}, 1 \mathrm{H}, \mathrm{ArH})$, $7.11(\mathrm{~s}, 1 \mathrm{H}, \mathrm{ArH}), 3.90\left(\mathrm{~s}, 3 \mathrm{H}, \mathrm{OCH}_{3}\right), 3.87\left(\mathrm{~s}, 3 \mathrm{H}, \mathrm{OCH}_{3}\right)$.

4-chloro-6,7-diethoxyquinazoline (8). Following a modified literature procedure ${ }^{33}$, DMF $(0.94 \mathrm{~mL}$, $12.1 \mathrm{mmol})$ was added dropwise to a solution of 1,2-dichloroethane $(8.1 \mathrm{~mL})$ and oxalyl chloride $(1.1$ $\mathrm{mL}, 12.6 \mathrm{mmol})$ stirring under argon, vigorously releasing gas. Following cessation of the gas production, 6,7-diethoxyquinazolin-4-one $6(1.89 \mathrm{~g}, 8.1 \mathrm{mmol})$ was added to the thick white slurry then refluxed for 2.5 hours, resulting in a yellow-brown suspension. The reaction was quenched by addition of $\mathrm{Na}_{2} \mathrm{HPO}_{4}(0.5 \mathrm{M}, 16.8 \mathrm{~mL})$ followed by stirring in an ice bath for 1 hour. The suspension was filtered and washed with water $(200 \mathrm{~mL})$ to isolate 4-chloro-6,7-diethyoxyquinazoline 8 as a pale gray solid, $1.48 \mathrm{~g}(73 \%) . \operatorname{mp~139-140}{ }^{\circ} \mathrm{C} ;{ }^{1} \mathrm{H}-\mathrm{NMR}\left(\mathrm{CDCl}_{3}\right): \delta 8.82(\mathrm{~s}, 1 \mathrm{H}, \mathrm{Ar} H), 7.35(\mathrm{~s}, 1 \mathrm{H}, \mathrm{Ar} H), 7.28(\mathrm{~s}, 1 \mathrm{H}$, $\mathrm{Ar} H), 4.26\left(\mathrm{~m}, 4 \mathrm{H}, \mathrm{OCH}_{2} \mathrm{CH}_{3}\right), 1.55\left(\mathrm{~m}, 6 \mathrm{H}, \mathrm{OCH}_{2} \mathrm{CH}_{3}\right)$. APCI MS [M+1] 253.1 (100), 255.1 (33). Anal. $\left(\mathrm{C}_{12} \mathrm{H}_{13} \mathrm{ClN}_{2} \mathrm{O}_{2}\right) \mathrm{C}, \mathrm{H}, \mathrm{N}$.

4-chloro-6,7-dimethoxyquinazoline (9). 6,7-dimethoxyquinazolin-4-one 7 (3.40 g, $16.5 \mathrm{mmol})$ was converted to 9 in $52 \%$ yield $(1.91 \mathrm{~g})$ following the procedure for compound 8 . mp $184-186{ }^{\circ} \mathrm{C}$; ${ }^{1} \mathrm{H}-$ $\left.\operatorname{NMR}\left(\mathrm{CDCl}_{3}\right): \delta 8.86(\mathrm{~s}, 1 \mathrm{H}, \mathrm{ArH}), 7.38(\mathrm{~s}, 1 \mathrm{H}, \mathrm{ArH}), 7.32(\mathrm{~s}, 1 \mathrm{H}, \mathrm{ArH}), 4.05(\mathrm{~s}, 6 \mathrm{H}, \mathrm{OCH})\right)$ APCI MS [M+1] 225.1 (100), 227.1 (30). Anal. $\left(\mathrm{C}_{10} \mathrm{H}_{9} \mathrm{ClN}_{2} \mathrm{O}_{2}\right) \mathrm{C}, \mathrm{H}, \mathrm{N}$. 
4-(3'-chloroanilino)-6,7-diethoxyquinazoline hydrochloride (10b): General coupling procedure. A solution of 4-chloro-6,7-diethoxyquinazoline $8(71 \mathrm{mg}, 0.32 \mathrm{mmol})$ and 3-chloroaniline (40 $\mu \mathrm{L}, 0.38$ $\mathrm{mmol}$ ) in $3 \mathrm{~mL}$ of DMF was heated at $80{ }^{\circ} \mathrm{C}$ under argon for $40 \mathrm{~min}$. The reaction was cooled at room temperature for 1 hour. Ethyl acetate $(2 \mathrm{~mL})$ was added. The resulting precipitate was filtered and further washed with $20 \mathrm{~mL}$ of ethyl acetate to give the $\mathrm{HCl}$ salt $10 \mathrm{a}, 100 \mathrm{mg}(90 \%)$. The salt was converted to the free base by dissolving $\mathbf{1 0 b}$ in a mixture of $3 \mathrm{~mL}$ of ethyl acetate and $3 \mathrm{~mL}$ of $1 \mathrm{~N}$ $\mathrm{NaOH}$. The biphasic mixture was stirred vigorously for several minutes. The ethyl acetate layer was filtered, washed with water $(3 \times 1 \mathrm{~mL})$ and dried over $\mathrm{MgSO}_{4}$. The ethyl acetate was filtered and the volume was reduced to less than $1 \mathrm{~mL}$. The solution was applied to a normal phase semi-preparative HPLC (Whatman M9/50 partisil 10 column, 70:30 EtOAc: hexane, $6 \mathrm{~mL} / \mathrm{min}$., UV $254 \mathrm{~nm}$ ) for purification. The fraction containing the free base was concentrated to dryness and the residue was dissolved in $\mathrm{MeOH}(8 \mathrm{~mL})$ with gentle heating. $\mathrm{HCl}(1 \mathrm{~N}, 3 \mathrm{~mL})$ was added and the solution was placed in an ice bath. The precipitate was filtered and washed with ethyl acetate to give $72 \mathrm{mg}(65 \%)$ of the 4(3-chloroanilino)-6,7-diethyoxyquinazoline hydrochloride salt 10b. mp 260-261 ${ }^{\circ} \mathrm{C} ;{ }^{1} \mathrm{H}$ NMR $\left(\mathrm{CD}_{3} \mathrm{OD}\right)$ $\delta 8.72(\mathrm{~s}, 1 \mathrm{H}, H-2), 7.97(\mathrm{~s}, 1 \mathrm{H}, \operatorname{Ar}-H), 7.87\left(\mathrm{~s}, 1 \mathrm{H}, H-2^{\prime}\right), 7.65\left(\mathrm{~d}, 1 \mathrm{H}, H-4^{\prime}, \mathrm{J}=8.0 \mathrm{~Hz}\right), 7.47$ (t, $1 \mathrm{H}, H-$ $\left.5^{\prime} \mathrm{J}=8.1 \mathrm{~Hz}\right), 7.35\left(\mathrm{~d}, 1 \mathrm{H}, H-6^{\prime}, \mathrm{J}=8.0 \mathrm{~Hz}\right), 7.20(\mathrm{~s}, 1 \mathrm{H}, \mathrm{Ar}-H), 4.31\left(\mathrm{q}, 4 \mathrm{H}, \mathrm{OCH}_{2} \mathrm{CH}_{3}, \mathrm{~J}=6.9 \mathrm{~Hz}\right)$, $1.55\left(\mathrm{t}, 6 \mathrm{H}, \mathrm{OCH}_{2} \mathrm{CH}_{3}, \mathrm{~J}=7.0 \mathrm{~Hz}\right)$. EI MS [M+] 343 (100), 345 (34). Anal. $\left(\mathrm{C}_{18} \mathrm{H}_{18} \mathrm{ClN}_{3} \mathrm{O}_{2}\right) \mathrm{C}, \mathrm{H}, \mathrm{N}$.

4-(3'-fluoroanilino)-6,7-diethoxyquinazoline hydrochloride (10a). Similar treatment of 8 (0.021g, $0.083 \mathrm{mmol}$ ) with 3-fluoroaniline yielded 10a (77\%).mp 247.0-248.0 ${ }^{\circ} \mathrm{C} ;{ }^{1} \mathrm{H}-\mathrm{NMR}\left(\mathrm{CD}_{3} \mathrm{OD}\right): \delta 8.73(\mathrm{~s}$, 1H, H-2), 7.99 (s, 1H, H-5), 7.66 (d, J=10.6 Hz, 1H, H-2'), 7.53 (m, 1H, H-5'), 7.53 (m, 1H, H-6'), 7.21 (s, $1 \mathrm{H}, \mathrm{H}-8), 7.08$ (dd, J=9.1, $7.1 \mathrm{~Hz}, 1 \mathrm{H}, \mathrm{H}-4$ '), 4.33 (q, J=6.9 Hz, 4H, $\mathrm{CH}_{3} \mathrm{CH}_{2} \mathrm{O}$ ), 1.55 (t, J=6.9 Hz, $\left.3 \mathrm{H}, \mathrm{CH}_{3} \mathrm{CH}_{2} \mathrm{O}\right), 1.54\left(\mathrm{t}, \mathrm{J}=6.9 \mathrm{~Hz}, 3 \mathrm{H}, \mathrm{CH}_{3} \mathrm{CH}_{2} \mathrm{O}\right)$. EI MS [M] 327. Anal. $\left(\mathrm{C}_{18} \mathrm{H}_{18} \mathrm{FN}_{3} \mathrm{O}_{2} \bullet \mathrm{HCl}\right) \mathrm{C}, \mathrm{H}$, N.

4-(3'-bromoanilino)-6,7-diethoxyquinazoline hydrochloride (10c). Similar treatment of 8 (59.5 mg, $0.24 \mathrm{mmol}$ ) with 3-bromoaniline yielded 10c $(50 \%) \mathrm{mp} 250-252{ }^{\circ} \mathrm{C}$ (Lit. ${ }^{33} \mathrm{mp} 155-167{ }^{\circ} \mathrm{C}-$ free base). ${ }^{1} \mathrm{H}$ NMR $\left[\left(\mathrm{CD}_{3}\right)_{2} \mathrm{SO}\right] \delta 11.17$ (br s, $\left.1 \mathrm{H}, \mathrm{N} H\right), 8.86$ (s, 1H, H-2), 8.19 (s, 1H, Ar- $\left.H\right), 7.99\left(\mathrm{~s}, 1 \mathrm{H}, H-2^{\prime}\right)$, 
$7.73\left(\mathrm{~d}, 1 \mathrm{H}, H-4^{\prime}, \mathrm{J}=7.6 \mathrm{~Hz}\right), 7.51\left(\mathrm{~d}, 1 \mathrm{H}, H-6^{\prime}, \mathrm{J}=7.5 \mathrm{~Hz}\right), 7.45\left(\mathrm{t}, 1 \mathrm{H}, H-5^{\prime} \mathrm{J}=8.0 \mathrm{~Hz}\right), 7.23(\mathrm{~s}, 1 \mathrm{H}$, Ar- $\mathrm{H}), 4.27\left(\mathrm{~m}, 4 \mathrm{H}, \mathrm{OCH}_{2} \mathrm{CH}_{3}, \mathrm{~J}=7.2 \mathrm{~Hz}\right), 1.45\left(\mathrm{t}, 6 \mathrm{H}, \mathrm{OCH}_{2} \mathrm{CH}_{3}, \mathrm{~J}=6.8 \mathrm{~Hz}\right)$. HREIMS Calc for $\mathrm{C}_{18} \mathrm{H}_{18} \mathrm{BrN}_{3} \mathrm{O}_{2} \mathrm{~m} / \mathrm{z}(\mathrm{M}+)$ 387.05824, 389.05619 found 387.05776, 389.05532 Anal. $\left(\mathrm{C}_{18} \mathrm{H}_{18} \mathrm{BrN}_{3} \mathrm{O}_{2}\right)$ $\mathrm{C}, \mathrm{H}, \mathrm{N}$.

4-(3'-iodoanilino)-6,7-diethoxyquinazoline hydrochloride (10d). Similar treatment of 8 (116.1 mg, $0.46 \mathrm{mmol}$ ) with 3-iodoaniline yielded 10d (95\%). mp 258.5-261 ${ }^{\circ} \mathrm{C}$; ${ }^{1} \mathrm{H}$ NMR $\left[\left(\mathrm{CD}_{3}\right)_{2} \mathrm{SO}\right] \delta 11.19$ (br s, $1 \mathrm{H}, \mathrm{N} H), 8.86$ (s, $1 \mathrm{H}, H-2), 8.19$ (s, 1H, Ar- $H), 8.10$ (s, $\left.1 \mathrm{H}, H-2^{\prime}\right), 7.75$ (d, $1 \mathrm{H}, H-4$ ', $\mathrm{J}=8.0 \mathrm{~Hz}$ ), 7.67 (d, 1H, H-6', J = 8.0 Hz), 7.30 (s, 1H, Ar- $H$ ), 7.29 (t, 1H, H-5' J = $8.0 \mathrm{~Hz}), 4.27$ (m, 4H, OCH $\mathrm{CH}_{3}$ ), $1.44\left(\mathrm{t}, 6 \mathrm{H}, \mathrm{OCH}_{2} \mathrm{CH}_{3}, \mathrm{~J}=6.8 \mathrm{~Hz}\right)$. APCI MS [M+1] $436.0(100)$. Anal. $\left(\mathrm{C}_{18} \mathrm{H}_{18} \mathrm{IN}_{3} \mathrm{O}_{2} \bullet \mathrm{HCl}\right) \mathrm{C}, \mathrm{H}, \mathrm{N}$.

4-(3'-fluoroanilino)-6,7-dimethoxyquinazoline hydrochloride (11a). Similar treatment of 9 ( $0.032 \mathrm{~g}$, $0.14 \mathrm{mmol}$ ) with 3-fluoroaniline yielded 11a (27\%). mp 244.5-246.0 ${ }^{\circ} \mathrm{C}$ (Lit. ${ }^{33} \mathrm{mp} 253-254{ }^{\circ} \mathrm{C}$ ); ${ }^{1} \mathrm{H}$ NMR (CD $\left.{ }_{3} \mathrm{OD}\right): \delta 8.72(\mathrm{~s}, 1 \mathrm{H}, H-2), 7.82(\mathrm{~s}, 1 \mathrm{H}, H-5), 7.47$ (d, J=10.6 Hz, 1H, $H-2$ '), $7.33(\mathrm{~m}, 1 \mathrm{H}, H-$ 5'), 7.33 (m, 1H, H-6'), 7.03 (s, $1 \mathrm{H}, H-8), 6.89$ (dd, J=8.6, $\left.7.3 \mathrm{~Hz}, 1 \mathrm{H}, H-4^{\prime}\right), 3.88$ (s, $6 \mathrm{H}, \mathrm{CH}_{3} \mathrm{O}$ ). EI MS [M] 299. Anal. $\left(\mathrm{C}_{16} \mathrm{H}_{14} \mathrm{FN}_{3} \mathrm{O}_{2} \bullet 1.1 \mathrm{HCl}\right) \mathrm{C}, \mathrm{H}, \mathrm{N}$.

4-(3'-chloroanilino)-6,7-dimethoxyquinazoline hydrochloride (11b). Similar treatment of 9 (71.1 $\mathrm{mg}, 0.32 \mathrm{mmol}$ ) with 3-chloroaniline yielded $11 \mathbf{b}(90 \%), \mathrm{mp} \mathrm{230-235}{ }^{\circ} \mathrm{C}$, (Lit. ${ }^{33} \mathrm{mp} \mathrm{261-262}{ }^{\circ} \mathrm{C}$ ); ${ }^{1} \mathrm{H}$ NMR (CD3OD) $\delta 8.66$ (s, 1H, H-2), 7.93 (s, 1H, Ar- $H$ ), 7.90 (s, 1H, H-2'), 7.66 (d, 1H, $H-4$ ', J = 8.0 Hz), $7.44\left(\mathrm{t}, 1 \mathrm{H}, H-5^{\prime} \mathrm{J}=8.1 \mathrm{~Hz}\right), 7.29(\mathrm{~d}, 1 \mathrm{H}, H-6$ ' J = $8.0 \mathrm{~Hz}), 7.21(\mathrm{~s}, 1 \mathrm{H}, \operatorname{Ar}-H), 4.02(\mathrm{~s}, 6 \mathrm{H}$, $\mathrm{OCH}_{3}$ ). HREIMS Calc for $\mathrm{C}_{16} \mathrm{H}_{14} \mathrm{ClN}_{3} \mathrm{O}_{2} \mathrm{~m} / \mathrm{z}(\mathrm{M}+)$ 315.07745, 317.07450 found 315.07682 , 317.07303. Anal. $\left(\mathrm{C}_{16} \mathrm{H}_{14} \mathrm{ClN}_{3} \mathrm{O}_{2} \bullet \mathrm{HCl}\right) \mathrm{C}, \mathrm{H}, \mathrm{N}$.

4-(3'-bromoanilino)-6,7-dimethoxyquinazoline hydrochloride (11c). Similar treatment of 9 (312 mg, $1.39 \mathrm{mmol})$ with 3-bromoaniline yielded 11c (87\%). mp 256-257.5 ${ }^{\circ} \mathrm{C} ;{ }^{1} \mathrm{H}$ NMR $\left[\left(\mathrm{CD}_{3}\right)_{2} \mathrm{SO}\right] \delta 11.35$ (br s, $1 \mathrm{H}, \mathrm{N} H), 8.88(\mathrm{~s}, 1 \mathrm{H}, H-2), 8.29$ (s, $1 \mathrm{H}, \mathrm{Ar}-H), 8.01$ (s, 1H, $\left.H-2^{\prime}\right), 7.77$ (d, $\left.1 \mathrm{H}, H-4^{\prime}, \mathrm{J}=8.0 \mathrm{~Hz}\right), 7.50$ 
(d, 1H, H-6', J = 8.0 Hz), 7.45 (t, 1H, H-5' J = 8.0 Hz), $7.32(\mathrm{~s}, 1 \mathrm{H}, \mathrm{Ar}-H), 4.00\left(\mathrm{~s}, 3 \mathrm{H}, \mathrm{OCH}_{3}\right), 3.99$ (s, $\left.3 \mathrm{H}, \mathrm{OCH}_{3}\right)$. EI MS [M+] 359 (100), 361 (97). Anal. $\left(\mathrm{C}_{16} \mathrm{H}_{14} \mathrm{BrN}_{3} \mathrm{O}_{2} \bullet \mathrm{HCl}\right) \mathrm{C}, \mathrm{H}, \mathrm{N}$.

4-(3'-iodoanilino)-6,7-dimethoxyquinazoline hydrochloride (11d). Similar treatment of 9 (276 mg, $1.23 \mathrm{mmol}$ ) with 3-iodoaniline yielded 11d (92\%). mp 251-251.5 ${ }^{\circ} \mathrm{C}$ (Lit. ${ }^{33} \mathrm{mp} 273{ }^{\circ} \mathrm{C}$ ). ${ }^{1} \mathrm{H}$ NMR $\left[\left(\mathrm{CD}_{3}\right)_{2} \mathrm{SO}\right] \delta 11.33$ (br s, $\left.1 \mathrm{H}, \mathrm{N} H\right), 8.90(\mathrm{~s}, 1 \mathrm{H}, H-2), 8.30$ (s, $\left.1 \mathrm{H}, \mathrm{Ar}-H\right), 8.28$ (s, $\left.1 \mathrm{H}, H-2^{\prime}\right), 7.79$ (d, 1H, $H-4$ ', J = $8.0 \mathrm{~Hz}), 7.69$ (d, 1H, H-6', J = $8.0 \mathrm{~Hz}$ ), 7.35 (s, 1H, Ar-H), 7.31 (t, 1H, H-5' J = $8.0 \mathrm{~Hz}$ ), $4.04\left(\mathrm{~s}, 3 \mathrm{H}, \mathrm{OCH}_{3}\right), 4.02\left(\mathrm{~s}, 3 \mathrm{H}, \mathrm{OCH}_{3}\right)$. APCI MS [M+1] 408.0 (100). Anal. $\left(\mathrm{C}_{16} \mathrm{H}_{14} \mathrm{IN}_{3} \mathrm{O}_{2} \bullet \mathrm{HCl}\right)$ $\mathrm{C}, \mathrm{H}, \mathrm{N}$.

4-(3'-fluoro-5' -trifluoromethylanilino)-6,7-diethoxyquinazoline hydrochloride (12). Similar treatment of 8 (58.5 mg, $0.23 \mathrm{mmol})$ with 3-fluoro-5-trifluoromethylaniline yielded 12 (92\%). mp 278$280^{\circ} \mathrm{C} ;{ }^{1} \mathrm{H}$ NMR $\left(\mathrm{CDCl}_{3}\right) \delta 8.70(\mathrm{~s}, 1 \mathrm{H}, H-2), 8.09\left(\mathrm{~d}, 1 \mathrm{H}, H-4{ }^{\prime}, \mathrm{J}_{\mathrm{H}, \mathrm{F}}=10.9\right), 7.62(\mathrm{~s}, 1 \mathrm{H}, \mathrm{Ar}-H), 7.26(\mathrm{~s}$, 1H, $\left.H-6^{\prime}\right), 7.22($ br s, $1 \mathrm{H}, \mathrm{N} H), 7.06\left(\mathrm{~d}, 1 \mathrm{H}, H-2^{\prime}, \mathrm{J}_{\mathrm{H}, \mathrm{F}}=8.0 \mathrm{~Hz}\right), 7.00(\mathrm{~s}, 1 \mathrm{H}, \mathrm{Ar}-H), 4.24(\mathrm{~m}, 4 \mathrm{H}$, $\left.\mathrm{OCH}_{2} \mathrm{CH}_{3}\right), 1.55\left(\mathrm{~m}, 6 \mathrm{H}, \mathrm{OCH}_{2} \mathrm{CH}_{3}\right)$. HREIMS Calc for $\mathrm{C}_{19} \mathrm{H}_{17} \mathrm{~F}_{4} \mathrm{~N}_{3} \mathrm{O}_{2} \mathrm{~m} / \mathrm{z}(\mathrm{M}+) 395.12569$ found 395.12596. Anal. $\left(\mathrm{C}_{19} \mathrm{H}_{17} \mathrm{~F}_{4} \mathrm{~N}_{3} \mathrm{O}_{2} \bullet \mathrm{HCl}\right) \mathrm{C}, \mathrm{H}, \mathrm{N}$.

4-(3'-fluoro-5'-trifluoromethylanilino)-6,7-dimethoxyquinazoline hydrochloride (13). Similar treatment of 9 (150 mg, $0.67 \mathrm{mmol}$ ) with 3-fluoro-5-trifluoromethylaniline yielded 13 (19\%). mp 269$270.5^{\circ} \mathrm{C} ;{ }^{1} \mathrm{H}$ NMR $\left(\mathrm{CDCl}_{3}\right) \delta 8.72(\mathrm{~s}, 1 \mathrm{H}, H-2), 8.08\left(\mathrm{~d}, 1 \mathrm{H}, H-4{ }^{\prime}, \mathrm{J}_{\mathrm{H}, \mathrm{F}}=10.8\right), 7.63(\mathrm{~s}, 1 \mathrm{H}, \mathrm{Ar}-H), 7.38$ (br s, 1H, NH), 7.27 (s, 1H, H-6'), $7.06\left(\mathrm{~d}, 1 \mathrm{H}, H-2^{\prime}, \mathrm{J}_{\mathrm{H}, \mathrm{F}}=8.4 \mathrm{~Hz}\right), 7.02(\mathrm{~s}, 1 \mathrm{H}, \mathrm{Ar}-H), 4.03(\mathrm{~s}, 3 \mathrm{H}$, $\left.\mathrm{OCH}_{3}\right), 4.01\left(\mathrm{~s}, 3 \mathrm{H}, \mathrm{OCH}_{3}\right)$. APCI MS [M+1] 368.1 (100). Anal. $\left(\mathrm{C}_{17} \mathrm{H}_{13} \mathrm{~F}_{4} \mathrm{~N}_{3} \mathrm{O}_{2} \bullet \mathrm{HCl}\right) \mathrm{C}, \mathrm{H}, \mathrm{N}$.

4-[(4'-fluorobenzyl)amino]-6,7-diethoxyquinazoline hydrochloride (14). Similar treatment of 8 (66.9 mg, $0.26 \mathrm{mmol}$ ) with 4-fluorobenzylamine yielded 14 (84\%). mp 238.5-240 ${ }^{\circ} \mathrm{C} ;{ }^{1} \mathrm{H} \mathrm{NMR}\left(\mathrm{CDCl}_{3}\right)$ $\delta 8.56(\mathrm{~s}, 1 \mathrm{H}, H-2), 7.37\left(\mathrm{dd}, 2 \mathrm{H}, H-2^{\prime}, H-6^{\prime}, \mathrm{J}_{\mathrm{H}, \mathrm{H}}=8.2, \mathrm{~J}_{\mathrm{H}, \mathrm{F}}=5.5\right), 7.18(\mathrm{~s}, 1 \mathrm{H}, \mathrm{Ar}-H), 7.03\left(\mathrm{t}, 2 \mathrm{H}, H-3^{\prime}\right.$, $\left.H-5^{\prime}, \mathrm{J}_{\mathrm{H}, \mathrm{F}}=\mathrm{J}_{\mathrm{H}, \mathrm{F}}=8.6 \mathrm{~Hz}\right), 6.84(\mathrm{~s}, 1 \mathrm{H}, \mathrm{Ar}-H), 5.53(\mathrm{br} \mathrm{s}, 1 \mathrm{H}, \mathrm{NH}), 4.81\left(\mathrm{~d}, 2 \mathrm{H},-\mathrm{CH} 2_{2^{-}}, \mathrm{J}=5.4\right), 4.20(\mathrm{q}$, 
$2 \mathrm{H}, \mathrm{OCH}_{2} \mathrm{CH}_{3}, \mathrm{~J}=7.0 \mathrm{~Hz}$ ), $4.12\left(\mathrm{q}, 2 \mathrm{H}, \mathrm{OCH}_{2} \mathrm{CH}_{3}, \mathrm{~J}=7.0 \mathrm{~Hz}\right), 1.51\left(\mathrm{t}, 3 \mathrm{H}, \mathrm{OCH}_{2} \mathrm{CH}_{3}, \mathrm{~J}=7.0 \mathrm{~Hz}\right)$, 1.49 (t, 3H, $\left.\mathrm{OCH}_{2} \mathrm{CH}_{3}, \mathrm{~J}=7.0 \mathrm{~Hz}\right)$. EI MS [M+1] 341 (100). Anal. $\left(\mathrm{C}_{19} \mathrm{H}_{20} \mathrm{FN}_{3} \mathrm{O}_{2}\right) \mathrm{C}, \mathrm{H}, \mathrm{N}$.

4-[(4'-fluorobenzyl)amino]-6,7-dimethoxyquinazoline hydrochloride (15). Similar treatment of 9 (320 mg, $0.1 .43 \mathrm{mmol}$ ) with 4-fluorobenzylamine yielded 15 (22\%). mp 250-251 ${ }^{\circ} \mathrm{C} ;{ }^{1} \mathrm{H}$ NMR $\left[\left(\mathrm{CD}_{3}\right)_{2} \mathrm{SO}\right] \delta 10.37(\mathrm{br} \mathrm{s}, 1 \mathrm{H}, \mathrm{N} H), 8.82(\mathrm{~s}, 1 \mathrm{H}, H-2), 8.00(\mathrm{~s}, 1 \mathrm{H}, \mathrm{Ar}-H), 7.45\left(\mathrm{dd}, 2 \mathrm{H}, H-2^{\prime}, H-6^{\prime}, \mathrm{J}_{\mathrm{H}, \mathrm{H}}\right.$ $\left.=8.4, \mathrm{~J}_{\mathrm{H}, \mathrm{F}}=5.6\right), 7.22(\mathrm{~s}, 1 \mathrm{H}, \mathrm{Ar}-H), 7.19\left(\mathrm{t}, 2 \mathrm{H}, H-3^{\prime}, H-5^{\prime}, \mathrm{J}_{\mathrm{H}, \mathrm{F}}=\mathrm{J}_{\mathrm{H}, \mathrm{F}}=8.8 \mathrm{~Hz}\right), 4.91\left(\mathrm{~d}, 2 \mathrm{H},-\mathrm{CH}_{2^{-}}, \mathrm{J}\right.$ $=5.2), \quad 3.95\left(\mathrm{~s}, 3 \mathrm{H}, \mathrm{OCH}_{3}\right), 3.94\left(\mathrm{~s}, 3 \mathrm{H}, \mathrm{OCH}_{3}\right) . \quad$ APCI MS [M+1] 314.2 (100). Anal. $\left(\mathrm{C}_{17} \mathrm{H}_{16} \mathrm{FN}_{3} \mathrm{O}_{2} \cdot \mathrm{HCl}\right) \mathrm{C}, \mathrm{H}, \mathrm{N}$.

4-(2'-fluoroanilino)-6,7-diethoxyquinazoline hydrochloride (16a). Similar treatment of $8(0.024 \mathrm{~g}$, $0.095 \mathrm{mmol}$ ) 2-fluoroaniline yielded 16a (61\%). mp 220.5-222.0 ${ }^{\circ} \mathrm{C} ;{ }^{1} \mathrm{H}-\mathrm{NMR}\left(\mathrm{CD}_{3} \mathrm{OD}\right): \delta 8.62(\mathrm{~s}, 1 \mathrm{H}$, $H-2$ ), 7.91 (s, 1H, H-5), 7.57 (dd, J=7.7, $\left.7.5 \mathrm{~Hz}, 1 \mathrm{H}, H-5^{\prime}\right), 7.44$ (m, 1H, $\left.H-4^{\prime}\right), 7.32$ (d, J=7.7 Hz, 1H, $H-$ 6'), $7.28\left(\mathrm{~m}, 1 \mathrm{H}, H-3^{\prime}\right), 7.20(\mathrm{~s}, 1 \mathrm{H}, H-8), 4.32$ (q, J=6.6 Hz, 2H, $\left.\mathrm{CH}_{3} \mathrm{CH}_{2} \mathrm{O}\right), 4.29$ (q, J=6.6 Hz, 2H, $\left.\mathrm{CH}_{3} \mathrm{CH}_{2} \mathrm{O}\right), 1.55\left(\mathrm{t}, \mathrm{J}=6.6 \mathrm{~Hz}, 3 \mathrm{H}, \mathrm{CH}_{3} \mathrm{CH}_{2} \mathrm{O}\right), 1.54\left(\mathrm{t}, \mathrm{J}=6.6 \mathrm{~Hz}, 3 \mathrm{H}, \mathrm{CH}_{3} \mathrm{CH}_{2} \mathrm{O}\right)$. HREIMS Calc for $\mathrm{C}_{18} \mathrm{H}_{18} \mathrm{FN}_{3} \mathrm{O}_{2} \mathrm{~m} / \mathrm{z}(\mathrm{M}+) 327.13831$ found 327.13779. Anal. $\left(\mathrm{C}_{18} \mathrm{H}_{18} \mathrm{FN}_{3} \mathrm{O}_{2} \bullet 1.4 \mathrm{HCl}\right) \mathrm{C}, \mathrm{H}, \mathrm{N}$.

4-(4'-fluoroanilino)-6,7-diethoxyquinazoline hydrochloride (16b). Similar treatment of 8 (0.10 g, $0.40 \mathrm{mmol})$ with 4-fluoroaniline yielded 16b (97\%). $\mathrm{mp} 252.0-255.0{ }^{\circ} \mathrm{C} ;{ }^{1} \mathrm{H}-\mathrm{NMR}\left(\left(\mathrm{CD}_{3}\right)_{2} \mathrm{SO}\right): \delta 10.06$ (s, 1H, NH), 8.77 (d, J=1.8 Hz, 1H, H-2), 8.27 (s, 1H, H-5), 7.68 (m, 2H, H-2', H-6'), 7.32 (s, 1H, H-8), $7.29\left(\mathrm{dd}, \mathrm{J}=6.7,6.6 \mathrm{~Hz}, 2 \mathrm{H}, \mathrm{H}-3^{\prime}, \mathrm{H}-5^{\prime}\right), 4.25$ (q, J=5.1 Hz, 2H, $\left.\mathrm{CH}_{3} \mathrm{CH}_{2} \mathrm{O}\right), 4.20(\mathrm{q}, \mathrm{J}=5.1 \mathrm{~Hz}, 2 \mathrm{H}$, $\left.\mathrm{CH}_{3} \mathrm{CH}_{2} \mathrm{O}\right), 1.41\left(\mathrm{t}, \mathrm{J}=5.1 \mathrm{~Hz}, 3 \mathrm{H}, \mathrm{CH}_{3} \mathrm{CH}_{2} \mathrm{O}\right), 1.40\left(\mathrm{t}, \mathrm{J}=5.1 \mathrm{~Hz}, 3 \mathrm{H}, \mathrm{CH}_{3} \mathrm{CH}_{2} \mathrm{O}\right)$. APCI MS [M+1] 328.3. Anal. $\left(\mathrm{C}_{18} \mathrm{H}_{18} \mathrm{FN}_{3} \mathrm{O}_{2} \cdot \mathrm{HCl}\right) \mathrm{C}, \mathrm{H}, \mathrm{N}$.

4-(2'-fluoroanilino)-6,7-dimethoxyquinazoline hydrochloride (17a). Similar treatment of $9(0.033 \mathrm{~g}$, $0.15 \mathrm{mmol}$ ) with 2-fluoroaniline yielded $17 \mathbf{a}(50 \%)$. mp 231.0-232.0 ${ }^{\circ} \mathrm{C} ;{ }^{1} \mathrm{H}-\mathrm{NMR}\left(\mathrm{CD}_{3} \mathrm{OD}\right): \delta 8.65$ (s, 
1H, $H-2), 7.97$ (s, 1H, H-5), 7.58 (ddd, J=7.7, $\left.7.5 \mathrm{~Hz}, 1.10 \mathrm{~Hz}, 1 \mathrm{H}, H-5^{\prime}\right), 7.44$ (m, 1H, $\left.H-4^{\prime}\right), 7.33$ (d, J=7.7 Hz, 1H, $\left.H-6^{\prime}\right), 7.29\left(\mathrm{~m}, 1 \mathrm{H}, H-3^{\prime}\right), 7.25(\mathrm{~s}, 1 \mathrm{H}, H-8), 4.09$ (s, 3H, CH$\left.H_{3} \mathrm{O}\right), 4.07$ (s, 3H, $\left.\mathrm{CH}_{3} \mathrm{O}\right)$. HREIMS Calc for $\mathrm{C}_{16} \mathrm{H}_{14} \mathrm{FN}_{3} \mathrm{O}_{2} \mathrm{~m} / \mathrm{z}(\mathrm{M}+) 299.10701$ found 299.10648. Anal. $\left(\mathrm{C}_{16} \mathrm{H}_{14} \mathrm{FN}_{3} \mathrm{O}_{2} \cdot \mathrm{HCl}\right)$ $\mathrm{C}, \mathrm{H}, \mathrm{N}$.

4-(4'-fluoroanilino)-6,7-dimethoxyquinazoline hydrochloride (17b). Similar treatment of 9 (0.10 g, $0.45 \mathrm{mmol})$ with 4-fluoroaniline yielded $\mathbf{1 7 b}(94 \%)$. mp 247.0-248.0 ${ }^{\circ} \mathrm{C} ;{ }^{1} \mathrm{H}-\mathrm{NMR}\left(\left(\mathrm{CD}_{3}\right)_{2} \mathrm{SO}\right): \delta 10.12$ (br. s, 1H, NH), 8.79 (s, 1H, H-2), 8.25 (s, 1H, H-5), 7.68 (m, 2H, H-2', H-6'), 7.30 (dd, J=7.0, $6.2 \mathrm{~Hz}$, 2H, $\left.H-3^{\prime}, H-5^{\prime}\right), 7.30(\mathrm{~s}, 1 \mathrm{H}, H-8), 3.98\left(\mathrm{~s}, 3 \mathrm{H}, \mathrm{CH} \mathrm{H}_{3} \mathrm{O}\right), 3.96\left(\mathrm{~s}, 3 \mathrm{H}, \mathrm{CH} \mathrm{H}_{3} \mathrm{O}\right)$. APCI MS [M+1] 300.1. Anal. $\left(\mathrm{C}_{16} \mathrm{H}_{14} \mathrm{FN}_{3} \mathrm{O}_{2} \cdot \mathrm{HCl}\right) \mathrm{C}, \mathrm{H}, \mathrm{N}$.

Log P Determinations. Log P values were estimated from the $\log \mathrm{k}_{\mathrm{w}}^{\prime}$ values determined by HPLC chromatography following the procedure of Minick. ${ }^{44}$ The solvents were HPLC grade methanol, 1octanol, $n$-decylamine and distilled deionized water. The standards (p-anisidine [0.95]; acetophenone [1.58]; p-bromoaniline [2.26]; naphthalene [3.30]; pyrene [4.88]) were obtained from Aldrich and used without further purification. A ThermoQuest HPLC system equipped with an autoinjector, pump, diode-array UV/Vis detector and an Es Industries MC8 column (4.6 x $150 \mathrm{~mm}, 5 \mu, 60 \AA)$ was used for these measurements. The organic mobile phase was methanol containing $0.25 \% \mathrm{v} / \mathrm{v} 1$-octanol. The aqueous mobile phase was octanol saturated water containing $0.02 \mathrm{M}$ 3-morpholinopropanesulfonic acid (MOPS) buffer, $0.15 \% \mathrm{v} / \mathrm{v} n$-decylamine, adjusted to $\mathrm{pH} 7.4$. The flow rate was set at $1 \mathrm{~mL} / \mathrm{min}$. The quinazolines and standards were dissolved in methanol to a final concentration of approximately $0.1 \mathrm{mg} /$ $\mathrm{mL}$ and $10 \mu \mathrm{L}$ was injected onto the column. The column void volume was estimated from the retention time of uracil, which was included as a non-retained internal reference standard with each injection. 
The $\log \mathrm{k}_{\mathrm{w}}^{\prime}$ was determined by linear extrapolation of the compound residence time (retention volume less void volume) versus the methanol concentration over a range of 60 to $85 \%$ methanol mobile phase.

\section{Biological Methods.}

Cell Lines and Cell Culture. The CEM human T lymphocyte cell line engineered to express ErbB4 $(\mathrm{CEM} / 4)$ and its culture conditions have been described previously. ${ }^{51,52}$ Briefly, these cells were propagated in RPMI supplemented with $10 \%$ heat-inactivated fetal bovine serum and $300 \mu \mathrm{g} / \mathrm{ml} \mathrm{G418.}$ The BaF3 mouse lymphoid cell lines engineered to express either EGFR (BaF3/EGFR) or ErbB2 and ErbB3 together $(\mathrm{BaF} 3 / 2+3)$ and the culture conditions for these cell lines have been described earlier. ${ }^{53}$ Briefly, these cells were propagated in RPMI supplemented with $10 \%$ fetal bovine serum, $300 \mu \mathrm{g} / \mathrm{ml}$ G418, and 10\% medium conditioned by WeHI cells. This conditioned medium serves as a source for Interleukin 3.

MCF-10A human mammary epithelial cells and MCF-7, MDA-MB-231, and MDA-MB-453 human mammary tumor cell lines were obtained from the American Type Culture Collection (ATCC). These lines were propagated according to ATCC recommendations.

Inhibition of Receptor Tyrosine Phosphorylation. The assay for inhibition of ErbB family receptor tyrosine phosphorylation was adapted from a previously-described protocol. ${ }^{52,53}$ Briefly, $200 \mathrm{~mL}$ cultures of $\mathrm{CEM} / 4, \mathrm{BaF} 3 / \mathrm{EGFR}$, or $\mathrm{BaF} 3 / 2+3$ cells were grown to saturation density $\left(\sim 10^{6}\right.$ cells $\left./ \mathrm{mL}\right)$ and were incubated for 24 hours at $37^{\circ} \mathrm{C}$ in serum-free medium to reduce basal levels of receptor tyrosine phosphorylation. The cells were collected by centrifugation and resuspended in serum-free medium at a final concentration of $\sim 10^{7}$ cells $/ \mathrm{mL}(\sim 20 \mathrm{~mL}$ of cells). Cells were transferred to microcentrifuge tubes in $1 \mathrm{~mL}$ aliquots and putative kinase inhibitors were added to the cells. Each tyrosine kinase inhibitor was tested at 3-5 different concentrations. The inhibitors were dissolved in 5 $\mu \mathrm{L}$ DMSO; hence, cells treated with $5 \mu \mathrm{L}$ DMSO were used as a solvent control. Cells were incubated 
in the presence of inhibitor for 2 hours at $37^{\circ} \mathrm{C}$, then were incubated on ice for 20 minutes. Chilling the cells reduces the amount of ligand-induced receptor downregulation. ${ }^{53}$

Ligand was then added to the appropriate samples at a final concentration of $100 \mathrm{ng} / \mathrm{mL}$ and the samples were mixed and incubated on ice for 7 minutes. Recombinant human Epidermal growth factor (EGF - Sigma) was used as the ligand for EGFR, whereas Neuregulin1 $\beta$ (NRG1 $\beta$ - R\&D Systems) was used as the ligand for ErbB3 and ErbB4. Note that because ErbB3 lacks kinase activity, ligand-induced ErbB2 and ErbB3 phosphorylation in the BaF3/2+3 cells is the result of ligand-induced ErbB2-ErbB3 heterodimerization and ErbB2 kinase activity. ${ }^{53}$ Following incubation with ligand, the cells were collected by centrifugation, the supernatant was removed by aspiration, and the cells were resuspended in an isotonic lysis buffer containing 0.5\% NP40/Igepal CA-630 (non-ionic detergent - Sigma).

The cells were incubated for 20 minutes on ice to permit lysis. The samples were centrifuged for 10 minutes at $4^{\circ} \mathrm{C}$ to collect the nuclei and cellular debris. The supernatants (cell lysates) were transferred to fresh tubes. Concanavalin A Sepharose (Amersham/Pharmacia) beads were added to each sample $\left(35 \mu \mathrm{L}\right.$ of a $50 \% \mathrm{v} / \mathrm{v}$ slurry) and the samples were incubated at $4^{\circ} \mathrm{C}$ for 30 minutes. Concanavalin A Sepharose precipitates the cellular glycoproteins, which include ErbB family receptors. The precipitated glycoproteins were washed three times with $500 \mu \mathrm{L}$ ice-cold lysis buffer, then were eluted by boiling the beads for five minutes in $80 \mu \mathrm{L}$ reducing SDS protein sample buffer. The beads were collected by centrifugation and half of the eluted glycoproteins $(40 \mu \mathrm{L})$ were recovered and resolved by SDS/PAGE on a 7.5\% acrylamide gel.

The resolved glycoproteins were electroblotted onto nitrocellulose (BiotraceNT - Gelman Sciences). The resulting blot was blocked by incubation for 45 minutes at room temperature in a solution consisting of 5\% bovine serum albumin (Sigma) dissolved in Tris-buffered normal saline (TBS) supplemented with $0.05 \%$ Tween-20 (TBS-T). The blot was then probed with a mouse monoclonal antiphosphotyrosine antibody (4G10 - Upstate Biotechnology). The blot was washed with TBS-T 5 
times for 6 minutes each, and primary antibody binding was detected by probing the blot with a goat anti-mouse antibody conjugated to horseradish perioxidase (HRP - Pierce). The blot was washed with TBS-T 12 times for 10 minutes each, after which HRP activity was visualized by enhanced chemiluminescence (ECL - Amersham Pharmacia Biotech). The resulting chemilumigrams were digitized using a Linotype-Hell Jade flatbed scanner and the amount of receptor tyrosine phosphorylation was quantified using NIH Image software. The amount of receptor tyrosine phosphorylation in samples from cells treated with a putative receptor tyrosine kinase inhibitor were compared to a standard curve generated using samples from cells treated with DMSO solvent control. This enabled us to determine the concentration of a given tyrosine kinase inhibitor that was necessary to cause a 50\% reduction in receptor tyrosine phosphorylation. This value is reported as the receptor tyrosine phosphorylation $\mathrm{IC}_{50}$ value.

Inhibition of Cellular DNA Synthesis. The assay for inhibition of cellular DNA synthesis was adapted from a previously-described protocol. ${ }^{54}$ Briefly, human mammary (tumor) cells were seeded in $1 \mathrm{~mL}$ aliquots into 24-well culture dishes at a density of $10^{5}$ cells/well. Cells were incubated for 24 hours at $37^{\circ} \mathrm{C}$, and a tyrosine kinase inhibitor dissolved in DMSO was added to each well in a volume of $10 \mu \mathrm{L}$. Each tyrosine kinase inhibitor was assayed at 3-5 different concentrations and each concentration was assayed using 3-4 wells of cells. Cells treated with $10 \mu \mathrm{LMSO}$ served as the solvent control. Cells were then incubated for 48 hours at $37^{\circ} \mathrm{C} .{ }^{3} \mathrm{H}$-Thymidine $(1.5 \mu \mathrm{Ci}$ - Amersham Pharmacia Biotech) dissolved in a $1.5 \mu \mathrm{L}$ of an aqueous solution was added to each well and the cells were incubated for an additional 2 hours at $37^{\circ} \mathrm{C}$. The culture medium was aspirated from the wells, and the cells were rinsed once with $1 \mathrm{~mL}$ ice-cold phosphate-buffered saline (PBS) and once with $1 \mathrm{~mL}$ ice-cold $10 \%$ trichloroacetic acid (TCA). Incorporated ${ }^{3} \mathrm{H}$-Thymidine was precipitated by incubating the cells for at least 30 minutes at $4^{\circ} \mathrm{C}$ in $1 \mathrm{~mL} 10 \%$ TCA. Following incubation, the TCA solution was aspirated from 
each well and the precipitated (incorporated) ${ }^{3} \mathrm{H}$-Thymidine was solubilized by incubating the cells for 30 minutes at $95^{\circ} \mathrm{C}$ in $500 \mu \mathrm{L} 3 \%$ perchloric acid. The perchloric acid extracts were transferred to scintillation vials containing $10 \mathrm{~mL}$ Cytoscint scintillation cocktail (ICN). The incorporated ${ }^{3} \mathrm{H}-$ Thymidine was assayed by scintillation counting on a Packard Tricarb scintillation counter. The amount of ${ }^{3} \mathrm{H}$-Thymidine incorporation observed in the cells treated with the solvent control was divided by 2 (two) to determine the amount of $1 / 2$ maximal ${ }^{3} \mathrm{H}$-Thymidine incorporation. Dose response curves for each combination of putative tyrosine kinase inhibitor and cell line were then constructed using the ${ }^{3} \mathrm{H}-$ Thymidine incorporation data. The dose response curves and the $1 / 2$ maximal ${ }^{3} \mathrm{H}$-Thymidine values were used to calculate the concentration of each inhibitor required to inhibit ${ }^{3} \mathrm{H}$-Thymidine incorporation by $50 \%$ in a given cell line. This value is reported as the DNA synthesis $\mathrm{IC}_{50}$ value.

In Vitro EGFR Binding Assay. EGFR tyrosine kinase receptor binding was determined by a competitive radiometric assay using [ $\left.{ }^{125} \mathrm{I}\right]-4-\left(3^{\prime}-\left[{ }^{125} \mathrm{I}\right]\right.$ iodoanilino $)-6,7-$ dimethoxyquinazoline $^{36}$ as the radiotracer (Specific Activity $=590 \mathrm{Ci} / \mathrm{mmol})$. Various concentrations $\left(10^{-11} \mathrm{M}-10^{-6} \mathrm{M}\right)$ of the quinazoline compounds were prepared in binding buffer (10 mM HEPES, $1 \mathrm{mM}$ EDTA, $5 \mathrm{mM} \mathrm{MgCl}_{2}$, 0.1\%BSA, $10 \mu \mathrm{g} / \mathrm{mL}$ leupeptin, $10 \mu \mathrm{g} / \mathrm{mL}$ pepstatin, $0.5 \mu \mathrm{g} / \mathrm{mL}$ aprotin and $200 \mu \mathrm{g} / \mathrm{mL}$ bacitracin $(\mathrm{pH}$ 7.4)). Commercially available (Receptor Biology, Beltsville, MD) A431 human carcinoma cell membrane were diluted in ice cold binding buffer $(50 \mu \mathrm{L}$ of $0.06 \mu \mathrm{g} / \mu \mathrm{L}$ stock solution)and homogenized with a hand held homogenizer. This preparation was added to the buffer solution followed by the addition of $1 \mu \mathrm{Ci}$ of the radiotracer to initiate the binding assay. The mixture was incubated at room temperature in the dark for $60 \mathrm{~min}$. The incubation was terminated by the addition of $5 \mathrm{~mL}$ of ice cold buffer (10 mM HEPES, $1 \mathrm{mM}$ EDTA, $5 \mathrm{mM} \mathrm{MgCl}_{2}$, and 0.1\% BSA (pH 7.4)) and the solutions were filtered through polyethylenamine soaked $(0.5 \%$ soln., $30 \mathrm{~min}) \mathrm{GF} / \mathrm{B}$ filter paper (Brandel, Gaithersburg, MD) using a Brandel Cell Harvester, followed by two washes (5 $\mathrm{mL}$ each) with wash buffer. The filter paper was dried and counted for 10 minutes using a TM Analytic gamma well counter. 
Non-specific binding was determined by adding $1 \mu \mathrm{M} 4-\left(3^{\prime}\right.$-bromoanilino)-dimethoxy quinazoline to the assay. Inhibition constants at $50 \%$ of specific binding $\left(\mathrm{IC}_{50}\right)$ were derived from specific binding versus concentration curves. Triplicate assays were performed for each compound.

\section{Acknowledgments}

This work was supported in part by the Director, Office of Science, Office of Biological and Environmental Research, Medical Science Division of the U.S. Department of Energy under contract No. DE-AC03-76SF00098, the Army Medical Research and Materiel Command, U.S. Department of Defense under grant no. DAMD17-98-1-8064 (HFV) and grant no. DAMD17-00-1-0415 (DJR), NIH National Cancer Institute under grant no. R21CA79823 (HFV), R01CA094253 (HFV) and R21CA80770 (DJR) and the California Breast Cancer Research Program under grant no. 4IB-0059 (HFV). Support for Dr. John Lim was provided by NIH National Cancer Institute training grant no. T32CA66527 through the UCSF Department of Radiology (Randall Hawkins, M.D., Ph.D., P.I.). The

authors wish to thank Dr. Scott Taylor for his helpful discussion and input on the radiometric binding assay. The authors also wish to thank Stephen Hanrahan for the preparation of the iodine-125 labeled quinazolines for the radiometric binding assay. 


\section{References}

(1) Hanks, S. K.; Quinn, A. M.; Hunter, T. The protein tyrosine kinase family: Conserved features and phylogeny of the catalytic domains. Science 1988, 241, 42-52.

(2) Ullrich, A.; Schlessinger, J. Signal transduction by receptors with tyrosine kinase activity. Cell 1990, 61, 203-212.

(3) Yarden, Y.; Ullrich, A. Growth Factor receptor tyrosine kinases. Ann. Rev. Biochem. 1988, 57, 443-478.

(4) Downward, J.; Yarden, Y.; Mayes, E.; Scrace, G.; Totty, N. et al. Close similarity of epidermal growth factor receptor and v-erb-B oncogene protein sequences. Nature 1984, 307, 521-527.

(5) Ullrich, A.; Coussens, L.; Hayflick, J. S.; Dull, T. J.; Gray, A. et al. Human epidermal growth factor receptor cDNA sequence and aberrant expression of the amplified gene in A431 epidermoid carcinoma cells. Nature 1984, 309, 418-425.

(6) Yarden, Y. The EGFR family and its ligands in human cancer: signalling mechanisms and the therapeutic opportunities. Eu. J. Cancer 2001, 37, S3-S8.

(7) Yarden, Y.; Sliwkowski, M. X. Untangling the ErbB signalling network. Nat. Rev. Mol. Cell Biol. 2001, 2, 127-137.

(8) Gasparini, G.; Bevilacqua, P.; Pozza, F.; Meli, S.; Boracchi, P. et al. Value of epidermal growth factor receptor status compared with growth fraction and other factors for prognosis in early breast cancer. Br. J. Cancer 1992, 66, 970-976.

(9) Toi, M.; Nakamura, T.; Mukaida, H.; Wada, T.; Osaki, A. et al. Relationship between epidermal growth factor receptor status and various prognostic factors in human breast cancer. Cancer 1990, $65,1980-1984$.

(10) Klijn, J.; Berns, P.; Schmitz, P.; Foekens, J. The clinical significance of epidermal growth factor receptor (EGF-R) in human breast cancer: A review on 5232 patients. Endocrine Rev. 1992, 13, 3-17. 
(11) Koenders, P.; Beex, L.; Geurts-Moespot, A.; Heuvel, J.; Kienhuis, C. et al. Epidermal growth factor receptor-negative tumors are predominantly confined to the subgroup of estradiol receptor-positive human primary breast cancers. Cancer Res. 1991, 51, 4544-4548.

(12) Mori, T.; Morimoto, T.; Komaki, K.; Monden, Y. Comparison of estrogen receptor and epidermal growth factor receptor content of primary and involved nodes in human breast cancer. Cancer 1991, 68, 532-537.

(13) Bridges, A. J. The rationale and strategy used to develop a series of highly potent, irreversible, inhibitors of the epidermal growth factor receptor family of tyrosine kinases. Curr. Med. Chem. 1999, 6, 825-843.

(14) Levitzki, A. Protein tyrosine kinase inhibitors as novel therapeutic agents. Pharmacol. Ther. 1999, $82,231-239$.

(15) Shawver, L. K.; Slamon, D.; Ullrich, A. Smart drugs: tyrosine kinase inhibitors in cancer therapy. Cancer Cell 2002, 1, 117-123.

(16) Traxler, P.; Furet, P. Strategies toward the design of novel and selective protein tyrosine kinase inhibitors. Pharmac. Ther. 1999, 82, 195-206.

(17) Woodburn, J. R. The epidermal growth factor receptor and its inhibition in cancer therapy. Pharmac. Ther. 1999, 82, 241-250.

(18) Mendelsohn, J.; Baselga, J. The EGF receptor family as targets for cancer therapy. Oncogene 2000, $19,6550-6565$.

(19) Carpenter, G. Receptors for epidermal growth factor and other polypeptide mitogens. Ann. Rev. Biochem. 1987, 56, 881-914.

(20) Andersson, A.; Capala, J.; Carlsson, J. Effects of EGF-dextran-tyrosine-131I conjugates on the clonogenic survival of cultured glioma cells. J. Neurooncol. 1992, 14, 213-223.

(21) Schatten, C.; Patiesky, N.; Vavra, N.; Ehrenbock, P.; Angelberger, P. et al. Lymphoscintigraphy with 123I-labeled epidermal growth factor. Lancet 1991, 337, 395-396. 
(22) Orlova, A.; Bruskin, A.; Sjostrom, A.; Lundqvist, H.; Gedda, L. et al. Cellular Processing of 125I- and 111In-labeled epidermal growth factor (EGF) bound to cultured A431 tumor cells. Nuc. Med. Biol. 2000, 27, 827-835.

(23) Capala, J.; Barth, R. F.; Bailey, M. Q.; Fenstermaker, R. A.; Marek, M. J. et al. Radiolabeling of epidermal growth factor with $99 \mathrm{mTc}$ and in vivo localization following intracerebral injection into normal and glioma-bearing rats. Bioconj. Chem. 1997, 8, 289-295.

(24) Rusckowski, M.; Qu, T.; Chang, F.; Hnatowich, D. J. Technetium-99m labeled epidermal growth factor-tumor imaging in mice. J. Peptide Res. 1997, 50, 393-401.

(25) Yang, W.; Barth, R. F.; Leveille, R.; Adams, D. M.; Ciesielski, M. et al. Evaluation of systemically administered radiolabeled epidermal growth factor as a brain tumor targeting agent. J. Neurooncol. 2001, 55, 19-28.

(26) Reilly, R. M.; Kiarash, R.; Cameron, R. G.; Porlier, N.; Sandhu, J. et al. 111In-labeled EGF is selectively radiotoxic to human breast cancer cells overexpressing EGFR. J. Nucl. Med. 2000, $41,429-438$.

(27) Remy, S.; Reilly, R.; Sheldon, K.; Gariepy, J. A new radioligand for the epidermal growth factor receptor: ${ }^{111}$ In labeled human epidermal growth factor derivitized with a bifunctional metalchelating peptide. Bioconj. Chem. 1995, 6, 683-690.

(28) Reilly, R. M.; Kiarash, R.; Sandhu, J.; Lee, Y. W.; Cameron, R. G. et al. A comparison of EGF and MAb 528 labeled with 111In for imaging human breast cancer. J. Nucl. Med. 2000, 41, 903911.

(29) Cammilleri, S.; Kaphan, G.; Berthois, Y.; Siles, S.; Khelifa, F. et al. Biodistribution and imaging studies with radioactively labeled monoclonal antibody anti-epidermal growth factor receptor in athymic mice bearing human mammary tumor. Antibody Immunoconjugates Radiopharm. 1991, 4, 501-506.

(30) Kalofonos, H.; Pawlikowska, T.; Hemingway, A.; Courtenay-Luck, N.; Dhokia, B. et al. Antibody guided diagnoisis and therapy of brain gliomas using radiolabeled monoclonal 
antibodies against epidermal growth factor receptor and placental alkaline phosphatase. J. Nucl. Med. 1989, 20, 1636-1645.

(31) Divgi, C. R.; Welt, S.; Kris, M.; Real, F. X.; Yeh, S. D. et al. Phase I and imaging trial of indium 111-labeled anti-epidermal growth factor receptor monoclonal antibody 225 in patients with squamous cell lung carcinoma [see comments]. J. Natl. Cancer Inst. 1991, 83, 97-104.

(32) Ramos-Suzarte, M.; Rodriguez, N.; Oliva, J. P.; Iznaga-Escobar, N.; Perera, A. et al. 99mTclabeled antihuman epidermal growth factor receptor antibody in patients with tumors of epithelial origin: Part III. Clinical trials safety and diagnostic efficacy. J. Nucl. Med. 1999, 40, 768-775.

(33) Bridges, A. J.; Zhou, H.; Cody, D. R.; Rewcastle, G. W.; McMichael, A. et al. Tyrosine kinase inhibitors. 8. An unusually steep structure-activity relationship for analogues of 4-(3bromoanilino)-6,7-dimethoxyquinazoline (PD 153035), a potent inhibitor of the epidermal growth factor receptor. J. Med. Chem. 1996, 39, 267-276.

(34) Fry, D.; Kraker, A.; McMichael, A.; Ambroso, L.; Nelson, J. et al. A specific inhibitor of the epidermal growth factor receptor tyrosine kinase. Science 1994, 265, 1093-1095.

(35) Rewcastle, G.; Denny, W.; Bridges, A.; Zhou, H.; Cody, D. et al. Tyrosine kinase inhibitors. 5. Synthesis and structure-activity relationships for 4-[(phenylmethyl)amino]- and 4(phenylamino)quinazolines as potent adenosine 5'-triphosphate binding site inhibitors of the tyrosine kinase domain of the epidermal growth factor receptor. J. Med. Chem. 1995, 38, 34823487.

(36) Lim, J. K.; Negash, K.; Hanrahan, S. M.; VanBrocklin, H. F. Synthesis of 4-(3'-[ ${ }^{[25}$ I]iodoanilino6,7-dialkoxyquinazolines: Radiolabeled epidermal growth factor tyrosine kinase inhibitors. $J$. Lab. Cmpd. Radiopharm. 2000, 43, 1183-1191.

(37) Mulholland, G. K.; Winkle, W.; Moch, B. H.; Sledge, G. Radioiodinated Epidermal Growth Factor Receptor Ligands as tumor probe. Dramatic potentiation of binding to MDA-486 cancer cells in presence of EGF. J. Nucl. Med. 1995, 36, 71P. 
(38) Bonasera, T. A.; Ortu, G.; Rozen, Y.; Krais, R.; Freedman, N. M. et al. Potential (18)F-labeled biomarkers for epidermal growth factor receptor tyrosine kinase. Nucl. Med. Biol. 2001, 28, 359374.

(39) Snyder, S. E.; Sherman, P. S.; Blair, J. B. 4-(3-chloro-4-[18F]fluorophenylamino)-6,7dimethoxyquinazoline: A radiolabeled EGF receptor inhibitor for imaging tumor biochemistry with PET. J. Nucl. Med. 2000, 41 Suppl., 233p.

(40) Mulholland, G. K.; Zheng, Q.-H.; Winkle, W. L.; Carlson, K. A. Synthesis and Biodistribution of new C-11 and F-18 labeled epidermal growth factor receptor ligands. J. Nucl. Med. 1997, 38, $141 \mathrm{P}$.

(41) Johnstrom, P.; Frediksson, A.; Thorell, J.-O.; Stone-Elander, S. Synthesis of [Methoxy11C]PD153035, a selective EGF receptor Tyrosine Kinase Inhibitor. J. Lab. Cmpd. Radiopharm. 1998, 41, 623-629.

(42) Frediksson, A.; Johnstrom, P.; Thorell, J.-O.; von Heijne, G.; Hassan, M. et al. In vivo evaluation of the biodistribution of 11C-labeled PD153035 in rats without and with neuroblastoma implants. Life Sci. 1999, 65, 165-174.

(43) Johnstrom, P.; Frediksson, A.; Thorell, J.-O.; Hassan, M.; Kogner, P. et al. Synthesis and in vivo biodistribution of tyrosine kinase inhibitor, [Methoxy-11C]PD 153035. J. Lab. Cmpd. Radiopharm. 1997, 40, 377-379.

(44) Minick, D.; Frenz, J.; Patrick, M.; Brent, D. A comprehensive method for determining hydrophobicity constants by reversed-phase high-performance liquid chromatography. $J$. Med. Chem. 1988, 31, 1923-1933.

(45) Pomper, M.; VanBrocklin, H.; Thieme, A.; Thomas, R.; Kiesewetter, D. et al. 11ß-methoxy-, $11 \beta$-ethyl- and $17 \alpha$-ethynyl-substituted $16 \alpha$-fluoroestradiols: receptor-based imaging agents with enhanced uptake efficiency and selectivity. J. Med. Chem. 1990, 33, 3143-3155.

(46) Eckelman, W. The application of receptor theory to receptor-binding and enzyme-binding oncologic radiopharmaceuticals. Nucl. Med. Biol. 1994, 21, 759-769.

(47) Eckelman, W. C. Sensitivity of New Radiopharmaceuticals. Nucl. Med. Biol. 1998, 25, 169-173. 
(48) Kuhnast, B.; Dolle, F.; Vaufrey, F.; Hinnen, F.; Crouzel, C. et al. Fluorine-18 labeling of oligonucleotides bearing chemically-modified ribose-phosphate backbones. J. Lab. Cmpd. Radiopharm. 2000, V43, 837-848.

(49) Mishani, E.; Cristel, M. E.; Dence, C. S.; McCarthy, T. J.; Welch, M. J. Application of a novel phenylpiperazine formation reaction to the radiosynthesis of a model fluorine-18-labeled radiopharmaceutical (18FTFMPP). Nucl. Med. Biol. 1997, 24, 269-273.

(50) Mu, F.; Coffing, S. L.; Riese, D. J. I.; Geahlen, R. L.; Verdier-Pinard, P. et al. Design, synthesis, and biological evaluation of a series of lavendustin A analogues that inhibit EGFR and Syk tyrosine kinases, as well as tubulin polymerization. J. Med. Chem. 2001, 44, 441-452.

(51) Plowman, G. D.; Green, J. M.; Culouscou, J. M.; Carlton, G. W.; Rothwell, V. M. et al. Heregulin induces tyrosine phosphorylation of HER4/p180erbB4. Nature 1993, 366, 473-475.

(52) Riese, D. J. I.; Komurasaki, T.; Plowman, G. D.; Stern, D. F. Activation of ErbB4 by the bifunctional epidermal growth factor family hormone epiregulin is regulated by ErbB2. J. Biol. Chem. 1998, 273, 11288-11294.

(53) Riese, D. J., 2nd; van Raaij, T. M.; Plowman, G. D.; Andrews, G. C.; Stern, D. F. The cellular response to neuregulins is governed by complex interactions of the erbB receptor family. [Erratum In: Mol Cell Biol 1996 Feb;16(2):735]. Mol. Cell. Biol. 1995, 15, 5770-5776.

(54) Hwang, E. S.; Riese, D. J. I.; Settleman, J.; Nilson, L. A.; Honig, J. et al. Inhibition of cervical carcinoma cell line proliferation by the introduction of a bovine papillomavirus regulatory gene. J. Virol. 1993, 67, 3720-3729.

(55) Gazit, A.; Osherov, N.; Gilon, C.; Levitzki, A. Tyrphostins. 6. Dimeric benzylidenemalononitrile tyrophostins: potent inhibitors of EGF receptor tyrosine kinase in vitro. J. Med. Chem. 1996, 39, 4905-4911.

(56) Dischino, D.D.; Welch, M.J.; Kilbourn, M.R.; Raichle, M.E. Relationship between lipophilicity and brain extraction of C-11 labeled radiopharmaceuticals. J. Nucl. Med. 1983, 24,1030-1038. 
(57) Katzenellenbogen, J.A.; Heiman, D.F.; Carlson, K.E.; Lloyd, J.E. In vivo and in vitro steroid receptor assays in the design of estrogen radiopharmaceuticals. In Eckelman, W.C. ReceptorBinding Radiotracers; CRC Press: Boca Raton, 1982; Volume I, Chapter 6; pp 93-126.

(58) Srinivasan, R., Poulsom, R., Hurst, H.C. and Gullick, W.J. Expression of the c-erbB-4/HER4 protein and mRNA in normal human fetal and adult tissues and in a survey of nine solid tumour types. J. Pathol. 1998, 185, 236-245.

(59) Bacus, S.S., Chin, D., Yarden, Y., Zelnick, C.R. and Stern, D.F. Type 1 receptor tyrosine kinases are differentially phosphorylated in mammary carcinoma and differentially associated with steroid receptors. Am. J. Pathol. 1996, 148, 549-558. 
Table 1. 4-Anilino- and 4-Benzylamino- Quinazolines Chemical and Physical Data.

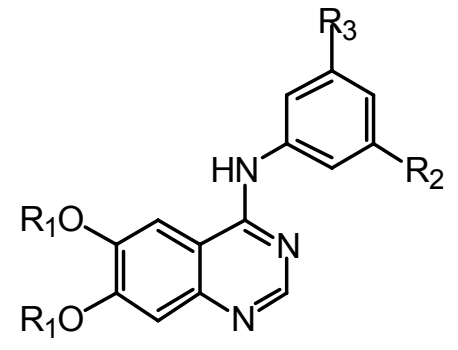

A

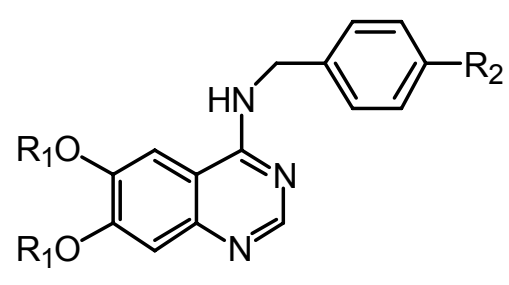

B<smiles>[R]Oc1cc2ncnc(Nc3ccc([R3])cc3[R])c2cc1O[R2]</smiles>

C

\begin{tabular}{|c|c|c|c|c|c|c|c|c|}
\hline no. & type & $\mathbf{R}_{1}$ & $\mathbf{R}_{\mathbf{2}}$ & $\mathbf{R}_{\mathbf{3}}$ & $\mathbf{m p}\left({ }^{\mathbf{0}} \mathrm{C}\right)$ & formula & anal. & $\log \mathbf{P}_{\mathbf{o} / \mathbf{w}}{ }^{a}$ \\
\hline $10 a$ & A & $\mathrm{CH}_{3} \mathrm{CH}_{2}$ & $\mathrm{~F}$ & $\mathrm{H}$ & $247-248$ & $\mathrm{C}_{18} \mathrm{H}_{18} \mathrm{FN}_{3} \mathrm{O}_{2} \cdot \mathrm{HCl}$ & $\mathrm{C}, \mathrm{H}, \mathrm{N}$ & $3.71 \pm 0.12$ \\
\hline $10 \mathrm{~b}$ & A & $\mathrm{CH}_{3} \mathrm{CH}_{2}$ & $\mathrm{Cl}$ & $\mathrm{H}$ & $260-261$ & $\mathrm{C}_{18} \mathrm{H}_{18} \mathrm{ClN}_{3} \mathrm{O}_{2} \cdot \mathrm{HCl}$ & $\mathrm{C}, \mathrm{H}, \mathrm{N}$ & $4.31 \pm 0.26$ \\
\hline $10 \mathrm{c}$ & A & $\mathrm{CH}_{3} \mathrm{CH}_{2}$ & $\mathrm{Br}$ & $\mathrm{H}$ & $250-252$ & $\mathrm{C}_{18} \mathrm{H}_{18} \mathrm{BrN}_{3} \mathrm{O}_{2}$ & $\mathrm{C}, \mathrm{H}, \mathrm{N}$ & $4.40 \pm 0.25$ \\
\hline 10d & A & $\mathrm{CH}_{3} \mathrm{CH}_{2}$ & I & $\mathrm{H}$ & $258-261$ & $\mathrm{C}_{18} \mathrm{H}_{18} \mathrm{IN}_{3} \mathrm{O}_{2} \cdot \mathrm{HCl}$ & $\mathrm{C}, \mathrm{H}, \mathrm{N}$ & $4.62 \pm 0.26$ \\
\hline $11 a$ & A & $\mathrm{CH}_{3}$ & $\mathrm{~F}$ & $\mathrm{H}$ & $244.5-246$ & $\mathrm{C}_{16} \mathrm{H}_{14} \mathrm{FN}_{3} \mathrm{O}_{2} \bullet 1.1 \mathrm{HCl}$ & $\mathrm{C}, \mathrm{H}, \mathrm{N}$ & $2.96 \pm 0.10$ \\
\hline 11b & A & $\mathrm{CH}_{3}$ & $\mathrm{Cl}$ & $\mathrm{H}$ & $230-235$ & $\mathrm{C}_{16} \mathrm{H}_{14} \mathrm{ClN}_{3} \mathrm{O}_{2} \cdot \mathrm{HCl}$ & $\mathrm{C}, \mathrm{H}, \mathrm{N}$ & $3.51 \pm 0.23$ \\
\hline $11 \mathrm{c}$ & A & $\mathrm{CH}_{3}$ & $\mathrm{Br}$ & $\mathrm{H}$ & $256-257.5$ & $\mathrm{C}_{16} \mathrm{H}_{14} \mathrm{BrN}_{3} \mathrm{O}_{2} \cdot \mathrm{HCl}$ & $\mathrm{C}, \mathrm{H}, \mathrm{N}$ & $3.49 \pm 0.22$ \\
\hline 11d & A & $\mathrm{CH}_{3}$ & I & $\mathrm{H}$ & $251-251.5$ & $\mathrm{C}_{16} \mathrm{H}_{14} \mathrm{IN}_{3} \mathrm{O}_{2} \cdot \mathrm{HCl}$ & $\mathrm{C}, \mathrm{H}, \mathrm{N}$ & $3.65 \pm 0.22$ \\
\hline 12 & A & $\mathrm{CH}_{3} \mathrm{CH}_{2}$ & $\mathrm{~F}$ & $\mathrm{CF}_{3}$ & $278-280$ & $\mathrm{C}_{19} \mathrm{H}_{17} \mathrm{~F}_{4} \mathrm{~N}_{3} \mathrm{O}_{2} \cdot \mathrm{HCl}$ & $\mathrm{C}, \mathrm{H}, \mathrm{N}$ & $5.49 \pm 0.29$ \\
\hline 13 & $\mathrm{~A}$ & $\mathrm{CH}_{3}$ & $\mathrm{~F}$ & $\mathrm{CF}_{3}$ & $269-270.5$ & $\mathrm{C}_{17} \mathrm{H}_{13} \mathrm{~F}_{4} \mathrm{~N}_{3} \mathrm{O}_{2} \cdot \mathrm{HCl}$ & $\mathrm{C}, \mathrm{H}, \mathrm{N}$ & $4.66 \pm 0.26$ \\
\hline 14 & B & $\mathrm{CH}_{3} \mathrm{CH}_{2}$ & $\mathrm{~F}$ & - & $238.5-240$ & $\mathrm{C}_{19} \mathrm{H}_{20} \mathrm{FN}_{3} \mathrm{O}_{2}$ & $\mathrm{C}, \mathrm{H}, \mathrm{N}$ & $3.78 \pm 0.23$ \\
\hline 15 & $\mathrm{~B}$ & $\mathrm{CH}_{3}$ & $\mathrm{~F}$ & - & $250-251$ & $\mathrm{C}_{17} \mathrm{H}_{16} \mathrm{FN}_{3} \mathrm{O}_{2} \cdot \mathrm{HCl}$ & $\mathrm{C}, \mathrm{H}, \mathrm{N}$ & $3.02 \pm 0.20$ \\
\hline $16 a$ & $\mathrm{C}$ & $\mathrm{CH}_{3} \mathrm{CH}_{2}$ & $\mathrm{~F}$ & $\mathrm{H}$ & $252-255$ & $\mathrm{C}_{18} \mathrm{H}_{18} \mathrm{FN}_{3} \mathrm{O}_{2} \bullet 1.4 \mathrm{HCl}$ & $\mathrm{C}, \mathrm{H}, \mathrm{N}$ & $3.02 \pm 0.11$ \\
\hline $16 b$ & $\mathrm{C}$ & $\mathrm{CH}_{3} \mathrm{CH}_{2}$ & $\mathrm{H}$ & $\mathrm{F}$ & $220.5-222$ & $\mathrm{C}_{18} \mathrm{H}_{18} \mathrm{FN}_{3} \mathrm{O}_{2} \cdot \mathrm{HCl}$ & $\mathrm{C}, \mathrm{H}, \mathrm{N}$ & $3.73 \pm 0.23$ \\
\hline $17 \mathbf{a}$ & $\mathrm{C}$ & $\mathrm{CH}_{3}$ & $\mathrm{~F}$ & $\mathrm{H}$ & $247-248$ & $\mathrm{C}_{16} \mathrm{H}_{14} \mathrm{FN}_{3} \mathrm{O}_{2} \cdot \mathrm{HCl}$ & $\mathrm{C}, \mathrm{H}, \mathrm{N}$ & $2.20 \pm 0.11$ \\
\hline $17 b$ & $\mathrm{C}$ & $\mathrm{CH}_{3}$ & $\mathrm{H}$ & $\mathrm{F}$ & $231-232$ & $\mathrm{C}_{16} \mathrm{H}_{14} \mathrm{FN}_{3} \mathrm{O}_{2} \cdot \mathrm{HCl}$ & $\mathrm{C}, \mathrm{H}, \mathrm{N}$ & $2.87 \pm 0.21$ \\
\hline
\end{tabular}

${ }^{a}$ Estimated by the reversed-phase HPLC method of Minick, et al. ${ }^{44}$ 
Table 2. Biochemical data for the EGFR tyrosine kinase (tk) inhibitors

\begin{tabular}{|c|c|c|c|c|}
\hline \multirow[b]{2}{*}{ no. } & \multirow{2}{*}{$\begin{array}{c}\text { Receptor Binding } \\
\left(\text { IC }_{50} \mathrm{nM}\right)\end{array}$} & \multicolumn{3}{|c|}{$\begin{array}{c}\text { Receptor Phosphorylation } \\
\left(\mathrm{IC}_{50} \mathrm{nM}\right)\end{array}$} \\
\hline & & EGFR tk & ErbB2 tk & ErbB4 tk \\
\hline $10 \mathrm{a}$ & $8.17 \pm 1.57$ & $6.5 \pm 2.1$ & & \\
\hline $10 \mathrm{~b}$ & $0.38 \pm 0.13$ & $1.2 \pm 0.2$ & & \\
\hline $10 \mathrm{c}$ & $0.41 \pm 0.09$ & $3.2 \pm 0.8$ & $215 \pm 87$ & $50 \pm 19$ \\
\hline $10 d$ & $0.64 \pm 0.15$ & $4.6 \pm 2.0$ & $69 \pm 10$ & $59 \pm 29$ \\
\hline 11a & $31.9 \pm 7.00$ & $6.3 \pm 2.0$ & & \\
\hline 11b & $1.26 \pm 0.00$ & $0.8 \pm 0.2$ & & \\
\hline $11 \mathrm{c}$ & $0.66 \pm 0.12$ & $2.6 \pm 0.5$ & $143 \pm 52$ & $49 \pm 16$ \\
\hline 11d & $1.05 \pm 0.51$ & $6.4 \pm 2.7$ & & \\
\hline 12 & $8.95 \pm 3.26$ & $>50$ & & \\
\hline 13 & $20.0 \pm 10.2$ & $19.1 \pm 2.9$ & & \\
\hline 14 & $17.0 \pm 5.0$ & $6.6 \pm 1.6$ & $231 \pm 92$ & $>100$ \\
\hline 15 & $47.7 \pm 14.1$ & $10.9 \pm 2.8$ & & \\
\hline $16 a$ & $9.31 \pm 1.19$ & $15.8 \pm 2.2$ & & \\
\hline $16 b$ & $16.0 \pm 3.7$ & $23.1 \pm 4.2$ & & \\
\hline $17 \mathbf{a}$ & $32.2 \pm 7.4$ & $12.8 \pm 3.5$ & & \\
\hline $17 b$ & $51.0 \pm 11.7$ & $19.1 \pm 2.5$ & & \\
\hline
\end{tabular}

Table 3. Inhibition of DNA Synthesis $\left(\mathrm{IC}_{50} \mathrm{nM}\right)$

\begin{tabular}{cccc}
\hline no. & MCF-10A $^{a}$ & MCF-7 $^{\boldsymbol{b}}$ & MCF-7/ MCF-10A $^{\mathbf{a}}$ \\
\hline $\mathbf{1 0 a}$ & $99 \pm 16$ & $1923 \pm 456$ & 19.5 \\
$\mathbf{1 0 b}$ & $108 \pm 8$ & $1087 \pm 402$ & 10.1 \\
$\mathbf{1 0 c}$ & $78 \pm 12$ & $1695 \pm 169$ & 21.7 \\
$\mathbf{1 0 d}$ & $153 \pm 25$ & $1571 \pm 263$ & 10.3 \\
$\mathbf{1 1 a}$ & $59 \pm 5$ & $1956 \pm 842$ & 33.2 \\
$\mathbf{1 1 b}$ & $173 \pm 24$ & $1982 \pm 387$ & 11.5 \\
$\mathbf{1 1 c}$ & $211 \pm 45$ & $1613 \pm 123$ & 7.6 \\
$\mathbf{1 1 d}$ & $585 \pm 108$ & $2433 \pm 61$ & 4.2 \\
$\mathbf{1 2}$ & $>3000$ & N.D. & -- \\
$\mathbf{1 3}$ & $1634 \pm 100$ & $4717 \pm 1014$ & 2.9 \\
$\mathbf{1 4}$ & $188 \pm 25$ & $1433 \pm 88$ & 7.6 \\
$\mathbf{1 5}$ & $489 \pm 87$ & $>7000$ & \\
$\mathbf{1 6 a}$ & $141 \pm 17$ & $1101 \pm 656$ & 7.8 \\
$\mathbf{1 6 b}$ & $622 \pm 69$ & $7487 \pm 505$ & 12.0
\end{tabular}


$\begin{array}{lllll}17 \mathbf{a} & 179 & \pm 31 & 1950 \pm 260 & 10.9\end{array}$

17b $\quad 612 \pm 134 \quad 3375 \pm 686 \quad 5.5$

${ }^{a}$ EGF-dependent human mammary epithelial cell line

${ }^{b}$ EGF-independent human mammary tumor cell line 


\section{Figure Captions:}

Figure 1. EGFR tyrosine kinase inhibitors ${ }^{13,16,34,55}$ 


\section{Figure 1.}

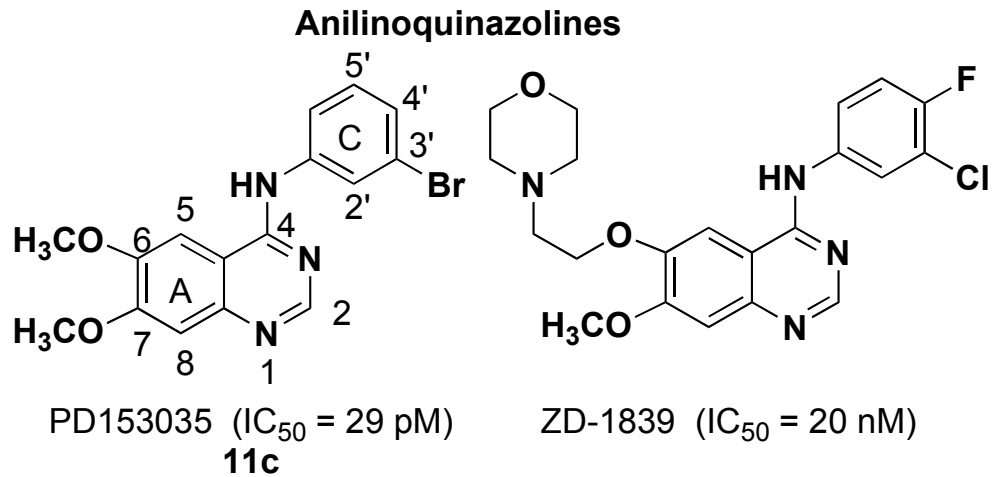

Tryphostins

Dianilinopthalimides

Lavendustin A<smiles>CO[Se]=[Se]C(C)(C)C(C)(C)C</smiles><smiles>[R]c1ccc(Nc2cc3c(cc2Nc2ccc([R])cc2)C(=O)NC3=O)cc1</smiles><smiles>O=C(O)c1cc(N(Cc2ccccc2O)Cc2cc(O)ccc2O)ccc1O</smiles>

Pyrrolo-Pyrimidines

$$
\begin{aligned}
& \mathrm{R}=\mathrm{H} \text { CGP } 52411\left(\mathrm{IC}_{50}=1-3 \mu \mathrm{M}\right) \\
& \mathrm{R}=\mathrm{F} \text { CGP } 53353\left(\mathrm{IC}_{50}=1-3 \mu \mathrm{M}\right)
\end{aligned}
$$

$\left(\mathrm{IC}_{50}=12 \mathrm{nM}\right)$<smiles>O=C(O)c1ccc(-c2cc3c(Nc4cccc(Cl)c4)ncnc3[nH]2)cc1</smiles>

\section{Scheme 1}<smiles>CCOc1ccc(C(=O)O)cc1OCC</smiles><smiles>CCOc1cc(N)c(C(=O)O)cc1OCC</smiles>

(i) $70 \% \mathrm{HNO}_{3} /$ glacial acetic acid/ $2 \mathrm{~h} / \mathrm{RT}$;

(ii) $\mathrm{SnCl}_{2} / \mathrm{HCl} / 2 \mathrm{~h} / \mathrm{RT}$; (iii) $\mathrm{NaOH} /$ reflux $/ 1 \mathrm{~h}$, then $\mathrm{HCl}$ 
Scheme 2

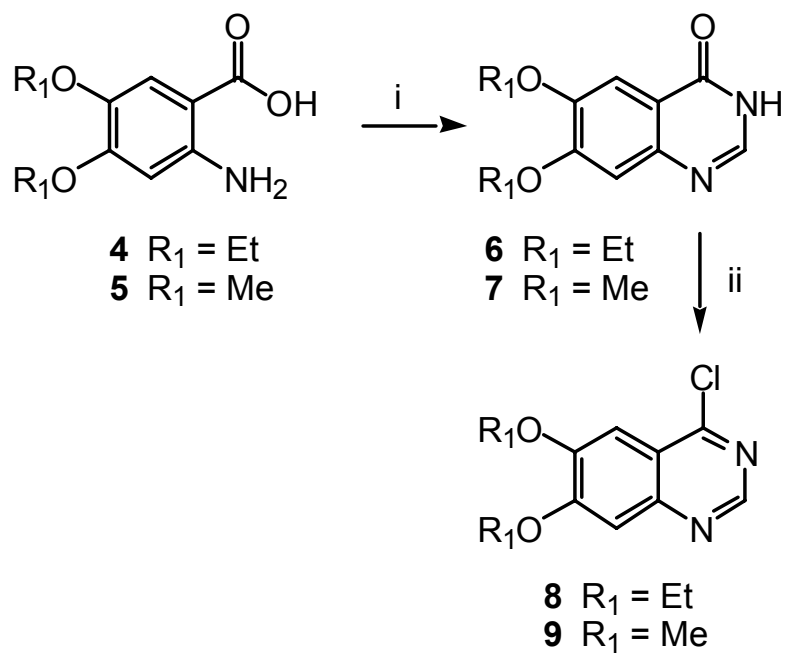

(i) formamidine $\cdot \mathrm{HCl} /$ heat then $\mathrm{NaOH} /$ sonicate/ $1 \mathrm{~h} / \mathrm{RT}$; (ii) oxalyl chloride/ DMF/

1,2-dichloroethane/ reflux 


\section{Scheme 3}<smiles>[R2]Oc1cc2ncnc(Nc3cccc([R2])c3)c2cc1O[R2]</smiles>

$10 \mathrm{R}_{1}=\mathrm{E}$

$$
\begin{aligned}
& \text { a } R_{2}=F \\
& \text { b } R_{2}=C l \\
& \text { c } R_{2}=B r \\
& \text { d } R_{2}=I
\end{aligned}
$$

$11 \mathrm{R}_{1}=\mathrm{Me} \quad \mathrm{a} \mathrm{R}_{2}=\mathrm{F}$

b $\mathrm{R}_{2}=\mathrm{Cl}$

c $\mathrm{R}_{2}=\mathrm{Br}$

d $R_{2}=1$

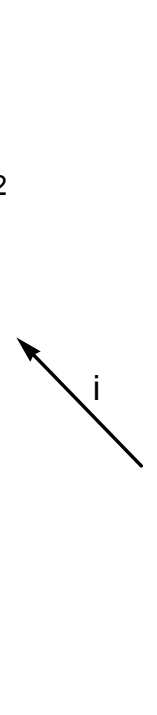<smiles>[R]Oc1cc2ncnc(Cl)c2cc1O[R2]</smiles>

$$
\begin{array}{ll}
8 & \mathrm{R}_{1}=\mathrm{Et} \\
9 & \mathrm{R}_{1}=\mathrm{Me}
\end{array}
$$

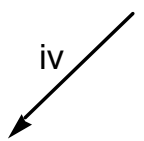<smiles>[R]Oc1cc2ncnc(Nc3ccc([R3])cc3[R2])c2cc1O[R2]</smiles>

$16 \mathrm{R}_{1}=\mathrm{Et}$

$$
\begin{aligned}
& \text { a } R_{2}=F, R_{3}=H \\
& \text { b } R_{2}=H, R_{3}=F
\end{aligned}
$$

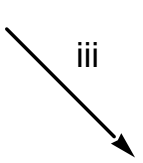

$12 \mathrm{R}_{1}=\mathrm{Et}$

$13 \mathrm{R}_{1}=\mathrm{Me}$

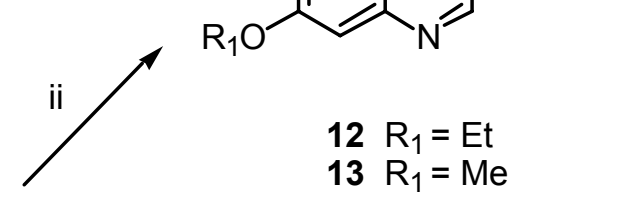

$17 R_{1}=M e \quad \begin{array}{ll}\text { a } R_{2}=F, R_{3}=H \\ \text { b } R_{2}=H, R_{3}=F\end{array}$

(i) 3-haloaniline/ DMF/ heat; (ii) 3-fluoro-5-trifluoromethylaniline/ DMF/ heat; (iii) 4-fluorobenzylamine/ DMF/ heat.; (iv) 2- or 4-fluoroaniline/ DMF/ Heat 
Table of Contents graphic

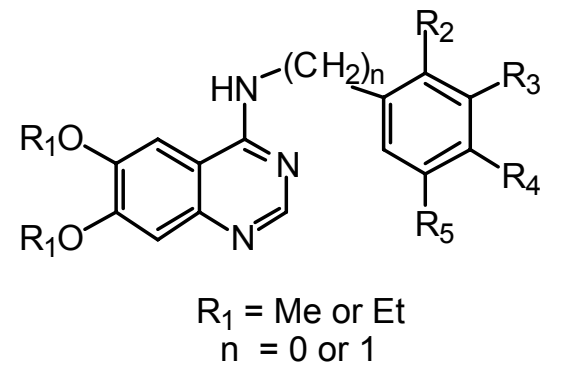

